\title{
The 129-iodine content of subtropical Pacific waters: impact of Fukushima and other anthropogenic 129-iodine sources
}

\author{
T. P. Guilderson ${ }^{1,2}$, S. J. Tumey ${ }^{1}$, T. A. Brown ${ }^{1}$, and K. O. Buesseler ${ }^{3}$ \\ ${ }^{1}$ Center for Accelerator Mass Spectrometry, Lawrence Livermore National Laboratory, Livermore, CA, USA \\ ${ }^{2}$ Department of Ocean Sciences and Institute of Marine Sciences, University of California, Santa Cruz, CA, USA \\ ${ }^{3}$ Department of Marine Chemistry and Geochemistry, Woods Hole Oceanographic Institution, Woods Hole, MA, USA
}

Correspondence to: T. P. Guilderson (tguilderson@1lnl.gov, tguilder@ucsc.edu)

Received: 18 November 2013 - Published in Biogeosciences Discuss.: 18 December 2013

Revised: 18 July 2014 - Accepted: 3 August 2014 - Published: 11 September 2014

\begin{abstract}
Results obtained from a dedicated radiochemistry cruise approximately 100 days after the 11 March 2011 Tohoku earthquake and subsequent disaster at the Fukushima Daiichi Nuclear Power Plant show that Fukushima derived radionuclides in the nearby ocean environment had penetrated, on average, to $\leq 250 \mathrm{~m}$ depth $\left(1026.5 \mathrm{~kg} \mathrm{~m}^{3}\right.$ potential density surface). The excess inventory of Fukushima-derived ${ }^{129}$ I in the region $\left(\sim 150000 \mathrm{~km}^{2}\right)$ sampled during the cruise is estimated to have been between 0.89 and 1.173 billion $\mathrm{Bq}$ ( $\sim 136$ to $\sim 179$ grams) of ${ }^{129}$ I. Based on a tight tracer-tracer relation with ${ }^{134} \mathrm{Cs}$ (or ${ }^{137} \mathrm{Cs}$ ) and estimates that most of the excess cesium is due to direct discharge, we infer that much of the excess ${ }^{129} \mathrm{I}$ is from direct (non-atmospheric deposition) discharge. After taking into account oceanic transport, we estimate the direct discharge, i.e., that directly released into the ocean, off Fukushima to have been $\sim 1 \mathrm{~kg}{ }^{129} \mathrm{I}$. Although this small pulse is dwarfed by the $\sim 90 \mathrm{~kg}$ of weaponstesting-derived ${ }^{129} \mathrm{I}$ that was released into the environment in the late 1950s and early 1960s, it should be possible to use Fukushima-derived ${ }^{129} \mathrm{I}$ and other radionuclides (e.g., ${ }^{134,137} \mathrm{Cs}$ ) to study transport and entrainment processes along and across the Kuroshio Current.
\end{abstract}

\section{Introduction}

Events related to the Tohoku earthquake and subsequent tsunami on 11 March 2011 resulted in catastrophic damage to the Fukushima Daiichi Nuclear Power Plant (NPP: $37^{\circ} 25^{\prime} \mathrm{N}$, $141^{\circ} 20^{\prime} \mathrm{E}$ ), which released a broad suite of radionuclides into the environment via atmospheric plumes and direct discharge into the nearby ocean. Included in the release were radioisotopes of iodine $\left({ }^{131} \mathrm{I}\right.$ and $\left.{ }^{129} \mathrm{I}\right)$. Due to its short ( $\sim 8$ day) halflife, ${ }^{131} \mathrm{I}$ has unique radiological hazards and is routinely measured for radiological assessments. On the other hand, ${ }^{129}$ I has a 15.7 million year half-life and is naturally produced via cosmic ray interactions with xenon and as a fission product of uranium has less of a direct radiological hazard, but can be used to retrospectively infer ${ }^{131}$ I release.

"Anthropogenic" ${ }^{129}$ I has been produced and dispersed into the ocean via atmospheric testing of nuclear weapons and, more recently, via reprocessing of spent nuclear fuel (Snyder et al., 2010 and references therein). Inorganic iodine is a micronutrient that is nearly conservative in seawater exhibiting only a weak depletion in surface waters relative to the deep ocean (e.g., Barkley and Thompson, 1960; Elderfield and Truesdale, 1980) and has a $\sim 3.4 \times 10^{5}$ year residence time (Broecker and Peng, 1982). Due to its anthropogenic atmospheric weapons testing input function and long oceanic residence time, ${ }^{129}$ I can be used as an oceanographic "conventional" transient tracer. Additionally, reprocessing facilities act like point sources and the release of ${ }^{129} \mathrm{I}$ can be also used to study local-regional dynamics. The most well known ${ }^{129}$ I tracer examples take advantage of the point source input into the North Atlantic, due to reprocessing at the La Hague (France) and Sellafield (England) facilities, to study the ventilation of the deep North Atlantic Ocean (e.g., Edmonds et al., 2001), and transport and mixing between the North Atlantic and the Arctic oceans (Smith et al., 2011 and references therein).

To investigate the input and dispersion of Fukushimaderived radionuclides into the western Pacific, a dedicated 

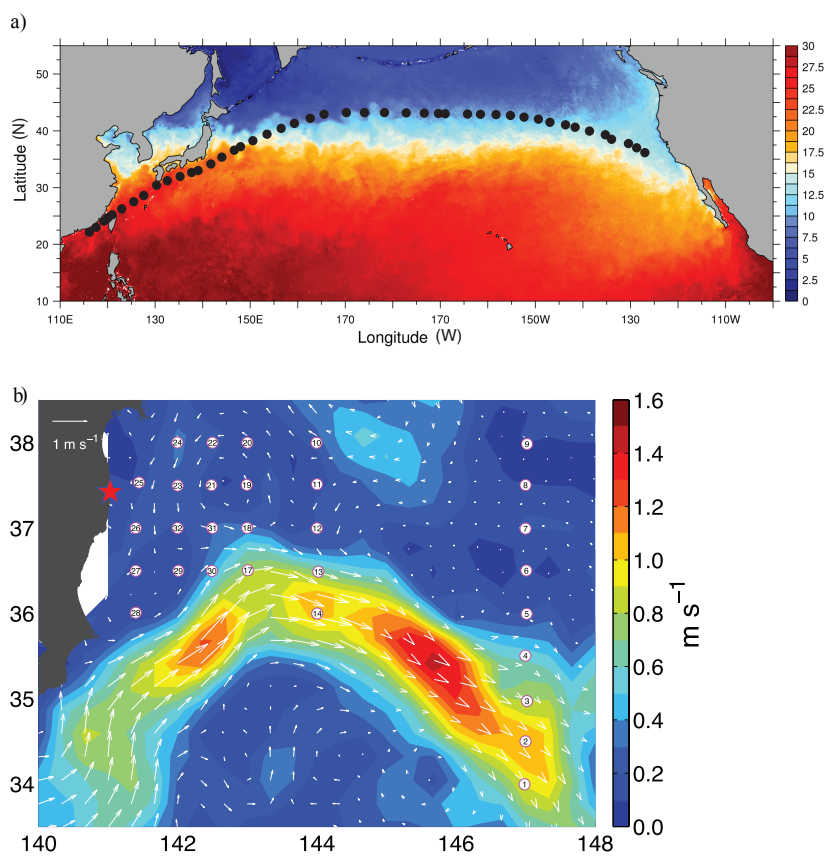

Figure 1. (a) Surface sample locations collected via the OOCL Tokyo (16-29 May 2011) overlain on level 4 global high-resolution sea surface temperature for May 232011 (http://podaac.jpl.nasa. gov/dataset/JPL-L4UHfnd-GLOB-MUR). The Kuroshio, which in general tracks the zero curl of the wind stress, separates cooler sub-polar water (blue colors) from warmer subtropical water (orange to red colors). (b) Hydrographic profile stations for the R/V Ka'imikai-o-Kanaloa cruise 1108b (3-17 June 2011) overlain on the first derivative of sea surface height which clearly delineates the Kuroshio Current as it sweeps eastward off Japan. Arrows are current velocity vectors. Figure modified from http://www.whoi.edu/ page.do?pid=67796 and Buesseler et al. (2012).

radiochemical and oceanography cruise was undertaken $\sim 100$ days after the Tohoku earthquake. Here, we report the impact of the Fukushima release on ${ }^{129} \mathrm{I}$ in oceanic waters. Additionally, we present the results of a May 2011 transPacific $\left(\sim 40^{\circ} \mathrm{N}\right)$ survey of surface water samples.

\section{Methods}

Seawater samples were collected during two separate cruises (Fig. 1). The first was a trans-Pacific transit (Hong Kong to Long Beach, CA) utilizing a Volunteer Observing Ship (VOS) container ship, the OOCL Tokyo (16-29 May 2011). Forty-five (45) surface samples and ancillary hydrographic data (temperature, salinity) were collected. The larger sample set was collected during a dedicated hydrographic and radiochemistry cruise onboard the R/V Ka'imikai-o-Kanaloa (KOK) 3-17 June 2011. The cruise plan for KOK 1108b has been previously described (Buesseler et al., 2012). Briefly, the cruise consisted of 32 sampling stations in a grid, 30 to $600 \mathrm{~km}$ offshore, to the east of Fukushima.
This region is part of the Kuroshio-Oyashio confluence zone, between the subtropical $\left(\sim 30-32^{\circ} \mathrm{N}\right)$ and subarctic $\left(\sim 40-42^{\circ} \mathrm{N}\right)$ fronts, (e.g., Talley, 1993; Qu et al., 2001; Ito and Yasuda, 2010) and is composed of four different water masses (subpolar, subtropical, "Tsugaru", and transitional water) and bounded to the south by the eastward flowing Kuroshio Current. The Kuroshio is the boundary current at the western edge of the subtropical gyre and has its origins near $10^{\circ} \mathrm{N}$ where the westward flowing North Equatorial Current, impinging on the Philippine Archipelago, bifurcates with the northern limb becoming the Kuroshio. During its northward transit and although anchored in deep water, its flow transits the shelf on the eastern edge of the East China Sea. Although mainly an eastward flowing current, the Kuroshio exhibits a tendency to generate large southward meanders between the Tokara Strait and Izu Ridge (e.g., Rommich and McCallister, 1989; Feng et al., 2000). Upon crossing the Izu Ridge and entering deep water, the structure of the Kuroshio extends to the bottom. The Kuroshio Extension, a drift current, delineates the northern edge of the subtropics and extends across the Pacific impinging on North America near $40^{\circ} \mathrm{N}$. The Oyashio Current is the southern boundary of the western locus of the subpolar gyre and has its origins with the East Kamchatka Current and the Okhotsk surface current. The Okhotsk surface current is itself an extension of the East Kamchatka Current, but which has undergone transformation while in the Sea of Okhotsk. The two currents recombine and become the Oyashio.

Sampling onboard the KOK was conducted using paired Niskin bottles on a CTD/rosette. Our samples are from nearshore stations 17, 18, 19, 20, 21, 22, 23, 24, 25, 26, 27, $28,29,30,31,32$, and offshore stations $5,6,7,8,9,10$, 11,12 , focusing on horizons less than $400 \mathrm{~m}$ water depth, but extending to depths as great as $\sim 1000 \mathrm{~m}$ at some stations. On the OOCL Tokyo, a continuous flow surface seawater line was used for sample collection, after the supply tap was opened and allowed to flow freely for several minutes. For sampling on both ships, bottles $(0.5 \mathrm{~L}, \mathrm{HDPE}$, acidcleaned with $2 \%$ nitric acid) were rinsed several times with sample water prior to filling. Bottles were filled, sealed, and taped, and stored in the dark.

${ }^{129}$ I analyses were made on total inorganic iodine. Iodine was extracted from seawater in a dedicated low-level ${ }^{129} \mathrm{I}$ preparation laboratory, using an adapted version (Tumey et al., 2013) of a commonly used solvent extraction procedure (Fehn et al., 1992; Michel et al., 2012; Moran et al., 1998; Schnabel et al., 2007; Sukuki et al., 2008). Briefly, $0.5 \mathrm{mg}$ of a very low ${ }^{129}$ I iodine carrier (Woodward Iodine Corporation; $\sim 2 \times 10^{-14}{ }^{129} \mathrm{I} /{ }^{127} \mathrm{I}$ ) was added to a $250 \mathrm{~mL}$ aliquot of each seawater sample, a carrier to sample ratio of $\sim 40: 1$. Through the addition of sodium sulfite and hydroxylamine hydrochloride dissolved inorganic iodine was reduce to iodide. The procedure calls for the addition of nitric acid following the sulfite and hydroxylamine additions. This addition reduces the $\mathrm{pH}$ and enables the reduction of iodate to 


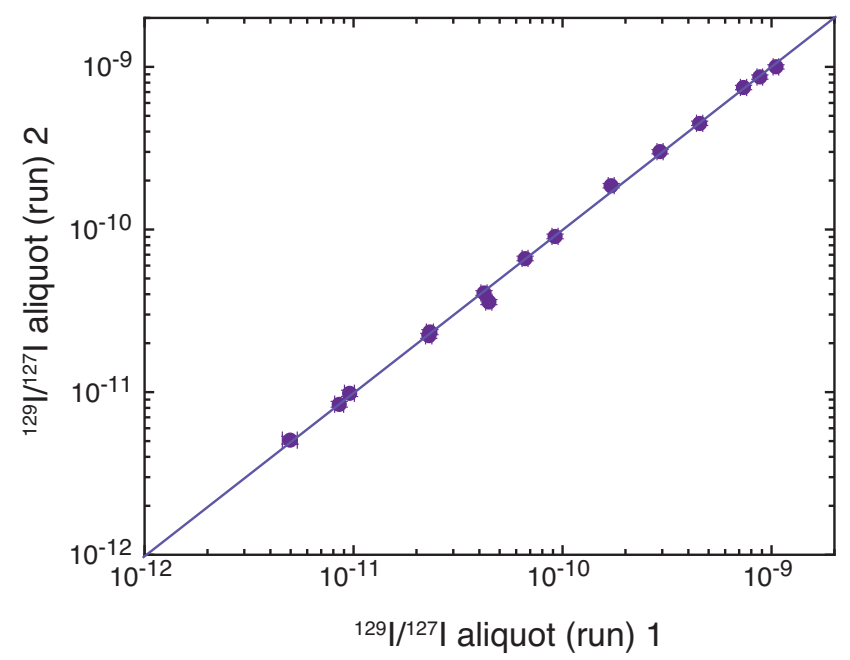

Figure 2. Independently prepared ${ }^{129}$ I replicate analyses prepared over an 8 month window are statistically indistinguishable from each other (reduced chi-squared of 1.1).

iodide. The resulting iodide was oxidized to molecular iodine by the addition of nitric acid and sodium nitrite. Molecular iodine was extracted into chloroform and then back extracted into an aqueous solution of sodium sulfite and potassium hydroxide. ${ }^{129}$ I analyses were made on silver iodide precipitated by the addition of silver nitrate. The precipitated silver iodide was rinsed with MQ water (3X), dried, and mechanically mixed with niobium powder prior to being loaded into individual stainless steel target holders.

Accelerator mass spectrometric analyses were made at the Center for Accelerator Mass Spectrometry (CAMS), Lawrence Livermore National Laboratory. Targets were analyzed in a sequence similar to that for ${ }^{14} \mathrm{C}$ at CAMS (e.g., Guilderson et al., 2003) and normalized against an inhouse prepared dilution of NIST SRM 4949C with Woodward Iodide. Targets were analyzed such that samples with a ${ }^{129} \mathrm{I} /{ }^{127}$ I ratio of $\geq 1 \times 10^{-11}$ were counted to $\sim 3 \%$ counting statistics. ${ }^{129} \mathrm{I} /{ }^{127} \mathrm{I}$ ratios for process blanks, prepared by running MQ water run through the full extraction procedure, averaged $3.8 \times 10^{-14}$ and were not subtracted from unknowns. A small set $(n=15)$ of samples spanning ${ }^{129} \mathrm{I} /{ }^{127} \mathrm{I}$ ratios from $\sim 5 \times 10^{-12}$ to $\sim 1 \times 10^{-9}$ that were independently prepared and replicated over an eight month window encompassing the measurements of the KOK and OOCL Tokyo samples have a reduced chi-squared of 1.1 and are, on average, statistically indistinguishable from each other (Fig. 2). A subset of these results has been previously reported in Tumey et al. (2013).

In much of the open ocean, total dissolved iodine (speciated between iodate and iodide) is constant to a few percent of a concentration of $\sim 60 \mu \mathrm{g}^{-1}$ (Barkley and Thompson, 1960; Elderfield and Truesdale, 1980; Nakayama et al., 1989). Such a value is consistent with iodine concentrations

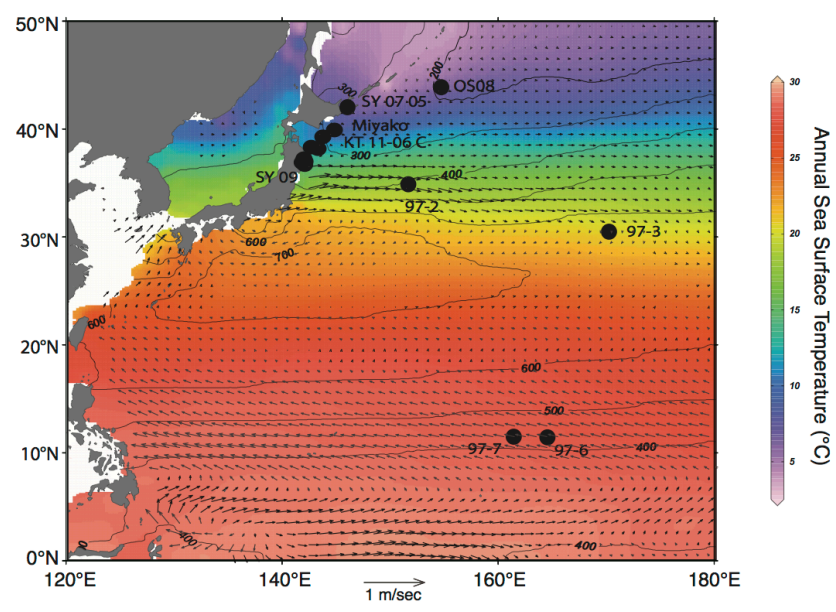

Figure 3. Northwestern Pacific hydrography and profile stations other than our own and discussed in the text. Color raster is the annual mean sea surface temperature $\left({ }^{\circ} \mathrm{C}\right)$ and thin black lines are the depth (meters) of the annual mean sigma $t_{0} 26.8 \mathrm{~kg} \mathrm{~m}^{-3}$ isopycnal from the World Ocean Atlas 2009 (http://www.nodc.noaa. gov/OC5/WOA09). Vectors are mean monthly sea surface currents (http://www.oscar.noaa.gov/). Stations plotted include the pre/postFukushima stations presented in Suzuki et al. (2013) and the profiles from the IAEA-97 cruise (Povinec et al., 2000, 2010). The pre-event profiles are demarked.

in waters off Japan with salinities $>30$ psu (Zheng et al., 2012). Salinities observed in the KOK hydrocasts had a limited range: $33.5-34.8$ psu. For the samples presented here, the salinity was $34.18 \pm 0.29$ psu ( 1 sigma SD). Therefore, we expect a limited range in total dissolved iodine concentrations, which is consistent with observations of [I] from a small subset of KOK samples (Hou et al., 2013). We use this value with an estimated uncertainty of $2 \mu \mathrm{g}^{-1}$ (1 sigma $\mathrm{SD}$ ) in calculating the ${ }^{129} \mathrm{I} /{ }^{127} \mathrm{I}$ ratios derived from our measurements of seawater samples in this paper. Total errors for ${ }^{129} \mathrm{I} /{ }^{127} \mathrm{I}$ ratios average $5 \%$.

We compare our results with data from the IAEA-97 radiochemistry cruise (Povinec et al., 2003) and individual profiles to the northeast of Japan (Suzuki et al., 2010, 2013). One of the IAEA-97 stations is from within the climatological mean of the Kuroshio near the northwest edge of the North Pacific subtropical gyre (NPSG), one station from just within the western NPSG, and two near the Marshall Islands from within the North Equatorial Current. The preFukushima profiles of Suzuki et al. $(2010,2013)$ include a subarctic site (OS8) and several within the confluence zone, where seasonally to interannually the site may be more or less influenced by subtropical surface water versus subarctic (Fig. 3). The North Pacific is only actively ventilated to $2000 \mathrm{~m}$ or less, coincident with the base of the wind driven circulation, with deeper portions forced remotely by the large-scale buoyancy-thermohaline circulation (e.g., Rommenich and McCallister, 1989). Turbulence along the NPSG 
boundary and within the Kuroshio confluence zone, where isopycnals are compressed, will mix tracers more efficiently than the interior of the NPSG where transport is slower (e.g., Kelley and Van Scoy 1999). In general the interior circulation at $\sim 1000 \mathrm{~m}$, with much slower velocities $\left(1-2 \mathrm{~cm} \mathrm{~s}^{-1}\right)$, has a similar pattern to the overlying surface current along its northern and western boundaries, although its eastward return flow is compressed poleward and the eastern boundary is diffuse to non-existent (e.g., Reid and Mantyla, 1978).

\section{Results}

We report results, which include an explicit correction for the carrier, as both ${ }^{129} \mathrm{I}$ activity per $\mathrm{m}^{3}$ and ${ }^{129} \mathrm{I} /{ }^{127} \mathrm{I}$. Consistent with previously published results we do not correct for process blanks. We note that for ${ }^{129} \mathrm{I} /{ }^{127} \mathrm{I}$ ratios of $\sim 1 \times 10^{-11}$ that the additional correction is on the order of $6 \%$ and decreases rapidly with higher ratios. The converse is also true: for ratios $\sim 5 \times 10^{-12}$ the additional correction is on the order of $15 \%$. We note that in our sample suite only thirteen samples (out of $>150$ measured) have carrier-corrected calculated ratios $<1 \times 10^{-11}$.

${ }^{129} \mathrm{I}$ results from the KOK $1108 \mathrm{~b}$ cruise and OOCL Tokyo are graphically shown as a function of potential density $\left(\mathrm{kg} \mathrm{m}^{-3}\right)$ in Fig. 4a. Lowest ${ }^{129} \mathrm{I} /{ }^{127} \mathrm{I}$ ratios $\left({ }^{129} \mathrm{I}\right.$ activities $)$ of $\leq 4.5 \times 10^{-12}\left(\sim 1.7 \times 10^{-6} \mathrm{~Bq} \mathrm{~m}^{-3}\right)$ are observed in the deepest samples analyzed $(\sim 1000 \mathrm{~m}$; densities $\left.\sim 1027.4 \mathrm{~kg} \mathrm{~m}^{-3}\right)$. ${ }^{129} \mathrm{I}$ increases with decreasing density (depth) to $\sim 1026.9 \mathrm{~kg} \mathrm{~m}^{-3}$ where there is a bifurcation. A suite of near-constant values at $\sim 3.5 \times 10^{-11}$ $\left(\sim 1.5 \times 10^{-5} \mathrm{~Bq} \mathrm{~m}^{-3}\right)$ track across (surface) densities to $\sim 1024.0 \mathrm{~kg} \mathrm{~m}^{-3}$, whereas the "spine" of the relation from higher densities continues to approximately $1026.4 \mathrm{~kg} \mathrm{~m}^{-3}$ and then the higher ${ }^{129} \mathrm{I}$ values scatter with no correlation to density from $\sim 1026.4$ to $\sim 1024.5 \mathrm{~kg} \mathrm{~m}^{-3}$. The maximum ${ }^{129}$ I value is $\sim 1.2 \times 10^{-9}\left(\sim 4.6 \times 10^{-4} \mathrm{~Bq} \mathrm{~m}^{-3}\right)$. Higher ${ }^{129}$ I values were obtained only for a subset of samples from depths shallower than $\sim 250 \mathrm{~m}$.

${ }^{129}$ I results from the OOCL Tokyo surface samples are generally $\sim 3.5 \times 10^{-11}{ }^{129} \mathrm{I} /{ }^{127} \mathrm{I}\left(\sim 1.5 \times 10^{-5} \mathrm{~Bq} \mathrm{~m}^{-3}\right)$ (Fig. 4a) and range from a low of $\sim 2.1 \times 10^{-11}$ $\left(\sim 8.3 \times 10^{-6} \mathrm{~Bq} \mathrm{~m}^{-3}\right)$ to a high of $\sim 1.3 \times 10^{-10}$ $\left(\sim 5.2 \times 10^{-5} \mathrm{~Bq} \mathrm{~m}^{-3}\right)$; there is no apparent relationship with density. The highest sample is from station 17 $\left(37.32^{\circ} \mathrm{N}, 147.82^{\circ} \mathrm{E}\right)$ just to the northeast of Fukushima. The following station $\left(18: 38.4^{\circ} \mathrm{N}, 150.45^{\circ} \mathrm{E}\right)$ is just under $4 \times 10^{-11}\left(\sim 1.5 \times 10^{-5} \mathrm{~Bq} \mathrm{~m}^{-3}\right)$. As a function of longitude, ${ }^{129} \mathrm{I}$ values are similar to $145^{\circ} \mathrm{W}$ and then increase as samples are taken in the California Current System (Fig. 4b).
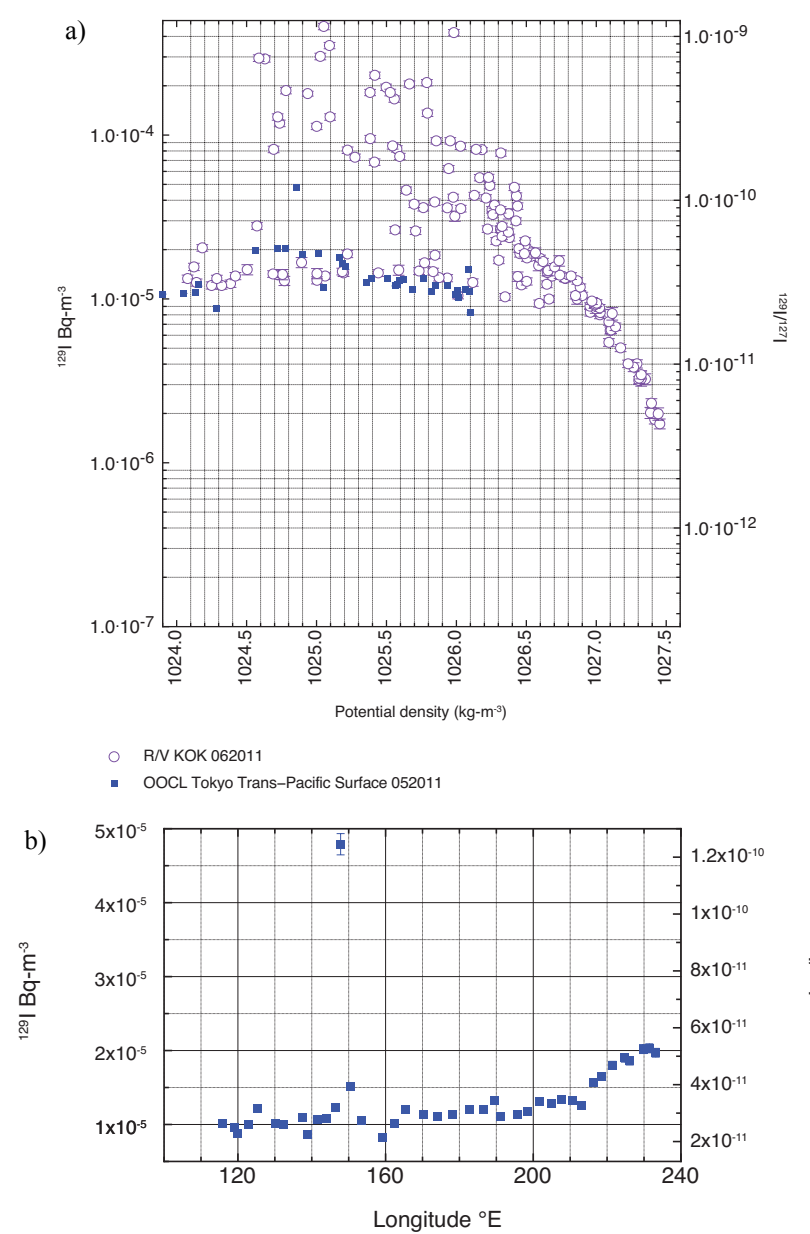

Figure 4. (a) Total dissolved inorganic ${ }^{129} \mathrm{I}$ in seawater as a function of potential density from the KOK $1108 \mathrm{~b}$ (open circles) and OOCL Tokyo samples (filled squares). (b) Surface ${ }^{129}$ I in seawater from the OOCL Tokyo as a function of longitude. For most of the data the uncertainties are the same size as the symbols. Results are shown as ${ }^{129} \mathrm{I} \mathrm{Bq} \mathrm{m}^{-3}$ and the equivalent approximate ${ }^{129} \mathrm{I} /{ }^{127} \mathrm{I}$ ratio.

\section{Discussion}

\subsection{Pre-Fukushima ${ }^{129} \mathrm{I}$ in the western Pacific}

In order to estimate the loading of Fukushima-derived ${ }^{129} \mathrm{I}$ it is necessary to determine or estimate the "pre-event" ${ }^{129} \mathrm{I}$ concentration (activity) or ${ }^{129} \mathrm{I} /{ }^{127} \mathrm{I}$ ratio. This assessment can be done using internal tracer-tracer (e.g., ${ }^{129} \mathrm{I}-{ }^{134} \mathrm{Cs}$ or ${ }^{137} \mathrm{Cs}$ ) relationships, "far-field" data from samples that are likely to be uninfluenced by Fukushima directly released effluent (but possibly influenced via atmospheric deposition), and local pre-Fukushima ${ }^{129} \mathrm{I}$ data.

Considerable effort has been devoted to the measurement of ${ }^{134} \mathrm{Cs}$ and ${ }^{137} \mathrm{Cs}$ in the samples obtained during the KOK cruise and an extensive data set has been published (Buesseler et al., 2012). These Cs isotope data, in conjunction 


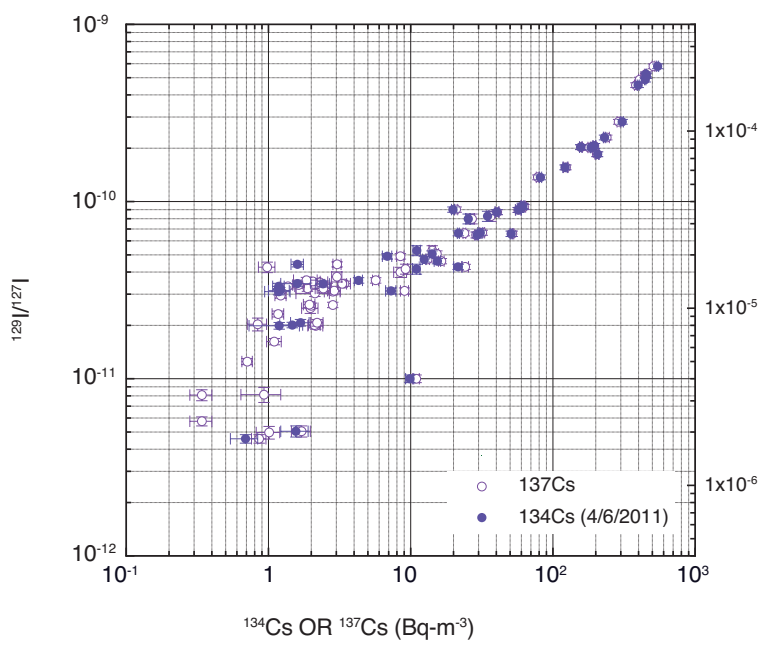

Figure 5. ${ }^{129} \mathrm{I}$ as a function of ${ }^{134} \mathrm{Cs}$ (and ${ }^{137} \mathrm{Cs}$ ) for exact same samples. Cesium data from Buesseler et al. (2012). ${ }^{134} \mathrm{Cs}$ has a reference (decay-corrected) date of 6 April 2011: the date of the highest direct discharge as indicated by The Tokyo Electric Power Company (TEPCO) and Ministry of Education, Culture, Sports, Science and Technology (MEXT) monitoring.

with our ${ }^{129}$ I KOK data, provide the basis for a tracer-tracer assessment of the "pre-event" ${ }^{129}$ I levels. Because of its 2 year half-life, any ${ }^{134} \mathrm{Cs}$ observed in the KOK sample suite and, more generally across the North Pacific, is Fukushimaderived (Aoyama et al., 2012, 2013; Buesseler et al., 2011, 2012 among others). This is in contrast to ${ }^{137} \mathrm{Cs}$ which, due to its 30 year half-life, has a small residual post-atmospheric weapons testing background of $\sim 1-2 \mathrm{~Bq} \mathrm{~m}^{-3}$ in surface waters (Aoyama et al., 2012, 2013; Buesseler et al., 2011 and references therein). Building on results presented in Tumey et al. (2013), but only using cesium-iodine pairs from niskin bottles collected at the same depth horizon on the same hydrographic cast $\left(n=46\right.$ for ${ }^{134} \mathrm{Cs}$ pairs and $n=69$ for ${ }^{137} \mathrm{Cs}$ pairs), we can see that there is a strong first-order linear correlation between ${ }^{134} \mathrm{Cs}\left({ }^{137} \mathrm{Cs}\right)$ and ${ }^{129} \mathrm{I}$ (Fig. 5). Graphically, there is a change in the slope of the relation when Cs activities are $<10 \mathrm{~Bq} \mathrm{~m}{ }^{3}$ and ${ }^{129} \mathrm{I}$ becomes approximately constant. There is a cluster of un-related data points at very low reported cesium activities. The former feature: near-constant ${ }^{129} \mathrm{I}$ for ${ }^{134} \mathrm{Cs}$ (and ${ }^{137} \mathrm{Cs}$ ) $<10 \mathrm{~Bq} \mathrm{~m}{ }^{-3}$, although possibly a reflection of differential input and in part visually exacerbated by the log-log plot, is very likely the consequence of dilution of Fukushima effluent with a fixed ${ }^{129} \mathrm{I} /{ }^{134} \mathrm{Cs}$ (or ${ }^{129} \mathrm{I} /{ }^{137} \mathrm{Cs}$ ) content diluted in background seawater: this is an expectation for a two isotope dilution model. The low Cs data points which seem to "falloff" the plot, reflect the entrainment of subsurface non-Fukushima labeled water with water that has been weakly impacted by Fukushima. Using all of the reported WHOI data, the projected zero ${ }^{134} \mathrm{Cs}$ activity intercept has a ${ }^{129} \mathrm{I} /{ }^{127} \mathrm{I}$ ratio of $1.3 \times 10^{-11}(95 \% \mathrm{CI}$ : $\left.1.26-1.34 \times 10^{-11}\right)$ or $4.5 \times 10^{-6} \mathrm{~Bq} \mathrm{~m}^{-3}$ (95\% CI: 4.29

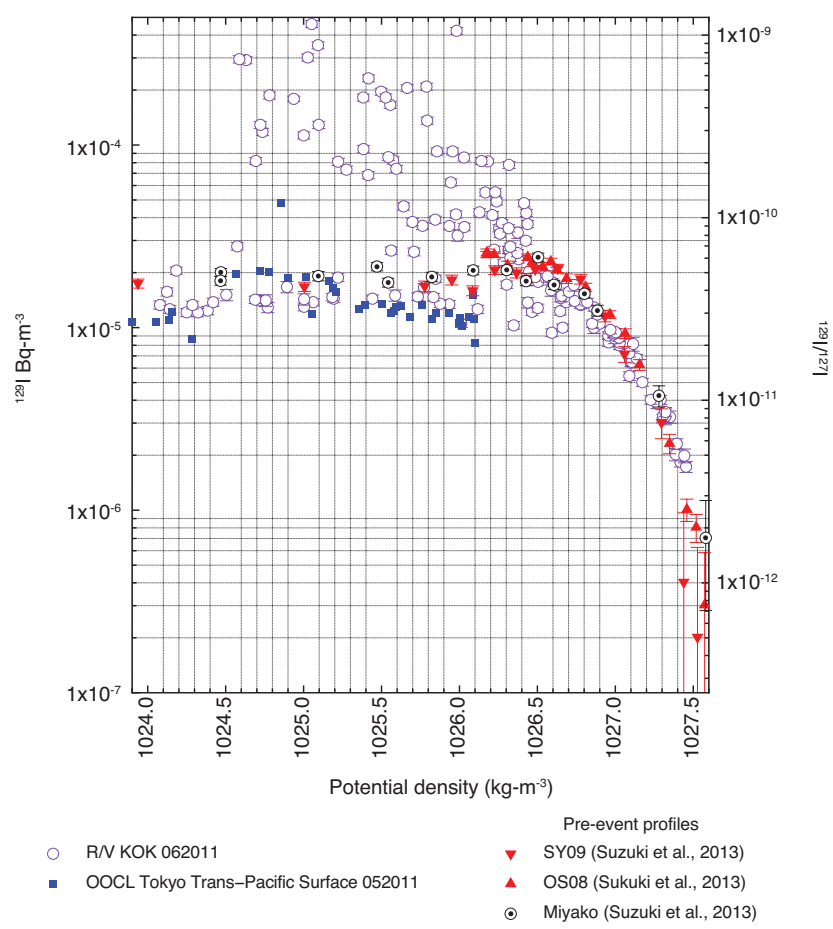

Figure 6. ${ }^{129} \mathrm{I}$ data from the KOK and OOCL Tokyo and data from three hydrographic stations (Suzuki et al., 2013) that were collected in 2008 and 2009: OS08 (filled triangles), SY09 (upside down triangles), Miyake (bulls eye). For clarity error bars are not plotted. For most of the data, the uncertainties are the same size of the symbols. Exceptions include the lowest values of Suzuki et al. (2013) where uncertainties are 100-1000\%.

$\left.4.67 \times 10^{-6}\right)$. If we restrict the analysis to results that are $\geq 1.5 \mathrm{~Bq} \mathrm{~m}^{-3}$, to avoid weakly impacted water that may have been subsequently modified by entrainment, and thus not simply reflecting the equivalent isotope-pulse chase dilution, the intercept is $2.4 \times 10^{-11}$ (95\% CI: $2.30-2.48 \times 10^{-11}$ ) or $8.6 \times 10^{-6} \mathrm{~Bq} \mathrm{~m}^{-3}\left(95 \% \mathrm{CI}: 8.13-9.02 \times 10^{-6}\right)$. Decay correcting the ${ }^{134} \mathrm{Cs}$ data from the reported 6 April 2011 reference of peak Fukushima input into the ocean to 11 March 2011, the date of the earthquake does not lead to a significant difference in these ${ }^{129} \mathrm{I}-{ }^{134} \mathrm{Cs}$ tracer-tracer intercept calculations of the "pre-event" ${ }^{129}$ I concentration (activity) or ${ }^{129} \mathrm{I} /{ }^{127} \mathrm{I}$ ratio.

Although we expect that some portion of the OOCL Tokyo surface samples could be impacted by Fukushima-derived ${ }^{129}$ I, particularly those directly to the east of Japan, we can compare these "far-field" data to provide an alternative assessment of the "pre-event" ${ }^{129}$ I levels. This provides insights on the spatial variability of the pre-event ${ }^{129}$ I in North Pacific surface waters, and the potential long-distance impact of Fukushima atmospheric fallout. The OOCL Tokyo sample suite is, for the most part, remarkably consistent. If we consider the section from Hong Kong to the dateline (an arbitrary but useful reference), there is one station (18: 
$37.32^{\circ} \mathrm{N}, 147.82^{\circ} \mathrm{E}$ ) that is clearly elevated with a ${ }^{129} \mathrm{I} /{ }^{127} \mathrm{I}$ of $1.26 \times 10^{-10}$ and the subsequent station $\left(19: 38.4^{\circ} \mathrm{N}\right.$, $150.45^{\circ} \mathrm{E}$ ) has a ratio of $3.96 \times 10^{-11}$. Without these two samples, the average of the remaining Hong Kong dateline samples is $(2.75 \pm 0.29) \times 10^{-11}(1$ sigma SD, $n=19)$, which is not significantly different from the ${ }^{134} \mathrm{Cs}$ derived intercept of $2.4 \times 10^{-11}$. Heading into the eastern North Pacific surface values are similar: $(3.13 \pm 0.18) \times 10^{-11}(1$ sigma $\mathrm{SD}, n=6$ ) to $\sim 161^{\circ} \mathrm{W}$. Going farther east and into the California Current System (CCS), ratios systematically increase to $(5.26 \pm 0.09) \times 10^{-11}$ for the last three stations (Fig. $4 \mathrm{~b}$ ).

Although not routinely measured on oceanographic samples, Suzuki et al. (2013) presented ${ }^{129}$ I data from three hydrographic casts off the northeast coast of Japan. One cruise occurred in 2008 (OS08, KNOT station: $154.97^{\circ} \mathrm{E}$, $43.97^{\circ} \mathrm{N}$ ) and two cruises in 2009 (SY09, Joban C station: $142.22^{\circ} \mathrm{E}, 36.80^{\circ} \mathrm{N}$; and Miyako from an undefined cruise: $145.0^{\circ} \mathrm{N}, 40.0^{\circ} \mathrm{N}$ ). The casts contained numerous discrete samples in the upper $100 \mathrm{~m}$ and extended to depths approaching $3000 \mathrm{~m}$. These stations allow us to assess the temporal variability in surface-mixed layer ${ }^{129} \mathrm{I}$ near Japan prior to March 2011. Using the nominally standard $0.125\left(\mathrm{~kg} \mathrm{~m}^{-3}\right)$ density difference criteria to define the mixed layer, mixed layer values from the three profiles are (expressed as $\left.{ }^{129} \mathrm{I} /{ }^{127} \mathrm{I}\right):(6.35 \pm 0.10) \times 10^{-11} \quad(n=2)$, $(4.47 \pm 0.12) \times 10^{-11}(n=3)$, and $(4.79 \pm 0.37) \times 10^{-11}$; $\begin{array}{lll}\left(\text { as } \quad{ }^{129} \mathrm{IBq} \mathrm{m}^{-3}\right): & (2.43 \pm 0.17) \times 10^{-5} & (1.77 \pm 0.57)\end{array}$ $\times 10^{-5}$, and $(1.89 \pm 0.14) \times 10^{-5}$, for the KNOT, Joban $\mathrm{C}$, and Miyako stations, respectively. Similar to the KOK data, Suzuki et al. (2013) ${ }^{129}$ I activities consistent with $\sim 2 \times 10^{-5} \mathrm{~Bq} \mathrm{~m}^{-3}$ exist to densities approaching $1026.75 \mathrm{~kg} \mathrm{~m}^{-3}$, indicating that for these three pre-event cruises, ${ }^{129}$ I was reasonably well mixed locally to a depth of $\sim 250 \mathrm{~m}$. At higher densities (deeper depths), the KOK and pre-event Suzuki et al., data are indistinguishable (Fig. 6).

The three independent methods to determine the pre-event ${ }^{129}$ I concentration, of which two are completely independent data sets, have produced estimates that are consistent with each other and indicate that over the recent past surface ${ }^{129} \mathrm{I}$ activities have been $1-2 \times 10^{-5} \mathrm{~Bq} \mathrm{~m}^{-3}$. As described by Suzuki et al. (2013) there may be a slight latitudinal dependence of ${ }^{129} \mathrm{I}$ in surface waters of the western subtropical North Pacific, although in the OOCL Tokyo data we do not observe any trend between $22^{\circ}$ and $35^{\circ}$ north latitude.

\subsection{Estimate of ${ }^{129} \mathrm{I} /{ }^{137} \mathrm{Cs}$ and ${ }^{129} \mathrm{I} /{ }^{134} \mathrm{Cs}$ off Fukushima in June 2011}

Using all of the WHOI cesium data, we estimate the ${ }^{129} \mathrm{I} /{ }^{134} \mathrm{Cs}$ and ${ }^{129} \mathrm{I} /{ }^{137} \mathrm{Cs}$ activity ratios (unitless) of a hypothetical Fukushima endmember via Keeling plot analysis (i.e., $1 / \mathrm{Cs}$ activity vs. $\left.{ }^{129} \mathrm{I} / \mathrm{Cs}\right)$, and obtain $3.9 \times 10^{-7}(95 \%$ CI: $\left.3.74-3.97 \times 10^{-7}\right)$ and $4.1 \times 10^{-7}$ (95\% CI: 3.95-4.19), respectively. The ${ }^{129} \mathrm{I} /{ }^{137} \mathrm{Cs}$ endmember estimate is insensitive to the small $\left(\sim 1-2 \mathrm{~Bq} \mathrm{~m}^{-3}\right)$ post-bomb oceanic back-

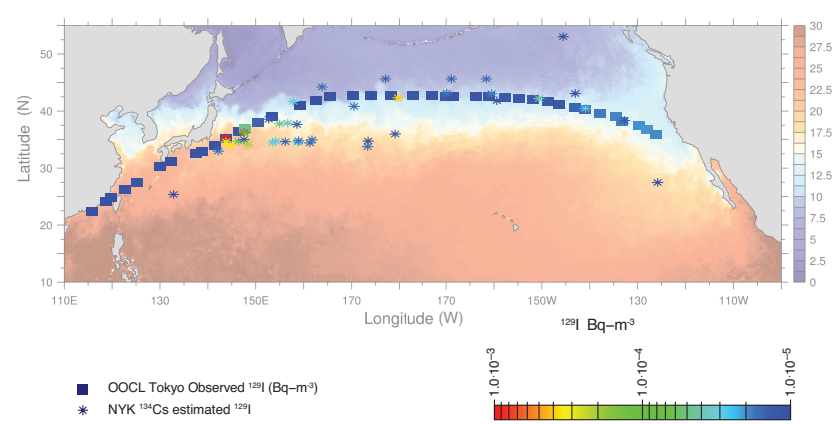

Figure 7. Estimated ${ }^{129} \mathrm{I}$ via atmospheric deposition (by way of ${ }^{137} \mathrm{Cs}$ and ${ }^{134} \mathrm{Cs}$ ) for Nippon Yusen Kaisha (NYK) surface samples (asterisks) collected at about the same time as the OOCL Tokyo (filled squares). NYK cesium data from Aoyama et al. (2012, 2013). The excess ${ }^{129} \mathrm{I}$ estimated via ${ }^{134} \mathrm{Cs}$ has been added to an average surface ocean background as described in the text. Translucent raster 23 May 2011 sea surface temperature whereas discrete point scale with ${ }^{129} \mathrm{IBq} \mathrm{m}^{-3}$.

ground activity. The ${ }^{129} \mathrm{I} /{ }^{134} \mathrm{Cs}$ endmember estimate from this data set is slightly sensitive to the chosen reference date; decay correcting the ${ }^{134} \mathrm{Cs}$ data from the defined (Buesseler et al., 2012) 6 April 2011 reference point (inferred maximum direct discharge date) to the 11 March 2011 date of the earthquake yields an activity ratio of $3.7 \times 10^{-7}$ (95\% CI: 3.62$3.84 \times 10^{-7}$ ).

\subsection{Estimating the influence of ${ }^{129}$ I atmospheric deposition}

Because ${ }^{129} \mathrm{I}$ has a much lesser potential radiological health impact than ${ }^{131} \mathrm{I}$ or ${ }^{134} \mathrm{Cs}$, observations of ${ }^{129} \mathrm{I}$ are not made as frequently. Many of the initial measurements by TEPCO, MEXT, and international radiological health effect assessments focused on ${ }^{131} \mathrm{I}$ and ${ }^{134} \mathrm{Cs}$, and other short half-life radionuclides (e.g., Masson et al., 2012 and references therein). To estimate the potential impact of deposition of ${ }^{129} \mathrm{I}$ in the northeastern Pacific and to constrain its influence on surface waters sampled by the OOCL Tokyo locations, where we observe a systematic increase in ${ }^{129} \mathrm{I}$, we can take advantage of tracer-tracer relations and observations of surface ${ }^{137} \mathrm{Cs}$ and ${ }^{134}$ Cs (Aoyoma et al., 2012, 2013).

Our ${ }^{129} \mathrm{I} /{ }^{134} \mathrm{Cs}$ (or ${ }^{129} \mathrm{I} /{ }^{137} \mathrm{Cs}$ ) relation for the KOK sample suite, which we assume to be mainly due to direct oceanic release, provides one potential relationship to estimate farfield atmospheric ${ }^{129}$ I deposition. However, it is likely to be incorrect because the chemistries of cesium and iodine are distinctly different, with iodine being much more volatile, whereas cesium has a tendency to be more quickly scavenged onto aerosols and particles: ie., the atmospheric relation may be different. Given that currently there are no direct measurements of ${ }^{129} \mathrm{I}$ in particulates and aerosols with corresponding cesium data, we estimate the atmospheric deposition from data derived from the US International Monitoring Sys- 
tem and Comprehensive Test Ban Treaty networks (cf. Biegaleski et al., 2012; Hoffman et al., 2012).

It should be noted that for the first month after the Tohoku earthquake and subsequent accident, the gaseous activity was $\geq 75 \%$ of the total (gaseous and particulate) measured ${ }^{131} \mathrm{I}$ activity (Masson et al., 2012), consistent with the relative efficacy of scavenging. Transfer times for the conversion of volatile iodine to particulate is on the order of several weeks; hence, gaseous iodine may provide a reservoir that can maintain and extend the influence of aerosol deposition of ${ }^{131} \mathrm{I}$ (cf. Uemetsu et al., 1988; Caput 1993; Achim et al., 2012; Masson et al., 2012; Kristiansen et al., 2013). Thus, the exercise below should be considered one possible endmember-based relation.

Post-event aerosol and particulate data document that the activity of ${ }^{137} \mathrm{Cs}$ to ${ }^{131} \mathrm{I}$ (decay corrected to release date) is $1-2 \%$ (Masson et al., 2012), i.e., a ${ }^{131} \mathrm{I} /{ }^{137} \mathrm{Cs}$ (activity) ratio of $\sim 66.7$. From measurements around Fukushima NPP the atom/atom ratio of ${ }^{129} \mathrm{I} /{ }^{131} \mathrm{I}$ of combined dry and particulate (rain-out) deposition is $31.6 \pm 9$ (Miyake et al., 2012) for a reference (decay corrected to) date of 15 March 2011 (the date of local maximum atmospheric radioactivity near the NPP), which when converted into an activity ratio is $\sim 4.5 \times 10^{-8}$. Taking the atom ratio back to 11 March 2011 yields an atom ratio of 22.4 and a ${ }^{129} \mathrm{I} /{ }^{131} \mathrm{I}$ activity ratio of $\sim 3.2 \times 10^{-8}$. Convolving the two relations yields a ${ }^{129} \mathrm{I} /{ }^{137} \mathrm{Cs}$ activity ratio of approximately $2.1 \times 10^{-6}$ (referenced to $11 \mathrm{March}$ ), and, because Fukushima-derived material has a ${ }^{134} \mathrm{Cs} /{ }^{137} \mathrm{Cs}$ activity ratio of 1 (Biegelski et al., 2012; Buesseler et al., 2011, 2012), also yield a ${ }^{129} \mathrm{I} /{ }^{134} \mathrm{Cs}$ activity ratio of $2.1 \times 110^{-6}$ (referenced to 11 March), which is an order of magnitude larger than the direct release relation derived above from the $\mathrm{KOK}$ sample suite. It is this $2.1 \times 110^{-6}{ }^{129} \mathrm{I} /{ }^{134} \mathrm{Cs}$ activity ratio that we use in the following to estimate the influence of atmospheric deposition of ${ }^{129} \mathrm{I}$.

To estimate the potential impact of atmospheric deposition, we utilize the surface VOS Nippon Yusen Kaisha (NYK) ${ }^{134}$ Cs data of Aoyoma et al. (2012). These samples, although not from the exact location and date as the OOCL Tokyo samples (being collected from 31st March to 17 th May), are reasonably contemporaneous. We decay correct the NYK ${ }^{134} \mathrm{Cs}$ data from the reported date of collection, which is the reference date for the decay-correction applied in reporting the ${ }^{134} \mathrm{Cs}$ data (Aoyama personal communication, 2013), to 11 March 2011. Using the above derived ${ }^{129} \mathrm{I} /{ }^{134} \mathrm{Cs}$ activity ratio and for NYK samples that detected ${ }^{134} \mathrm{Cs}$, the estimated excess ${ }^{129} \mathrm{I}$ (i.e., added upon the background surface $\left.{ }^{129} \mathrm{I}\right)$ ranges from very low ${ }^{129} \mathrm{I}_{\left(\mathrm{Bq} \mathrm{m}^{-3}\right)}$ values of $1.3 \times 10^{-6}\left(0.6 \mathrm{~Bq} \mathrm{~m}^{-3}\right.$ of $\left.{ }^{134} \mathrm{Cs}\right)$ to $2.2 \times 10^{-3}$ $\left(1028 \mathrm{~Bq} \mathrm{~m}^{-3}\right.$ of ${ }^{134} \mathrm{Cs}$ ) (Fig. 7). The implied potential atmospheric deposition of ${ }^{129}$ I into surface waters implied by the NYK data is, for the most part, similar to that observed by our OOCL Tokyo samples. Even if the ${ }^{129} \mathrm{I}-{ }^{134} \mathrm{Cs}$ relation is an order of magnitude larger, the NYK data imply that a

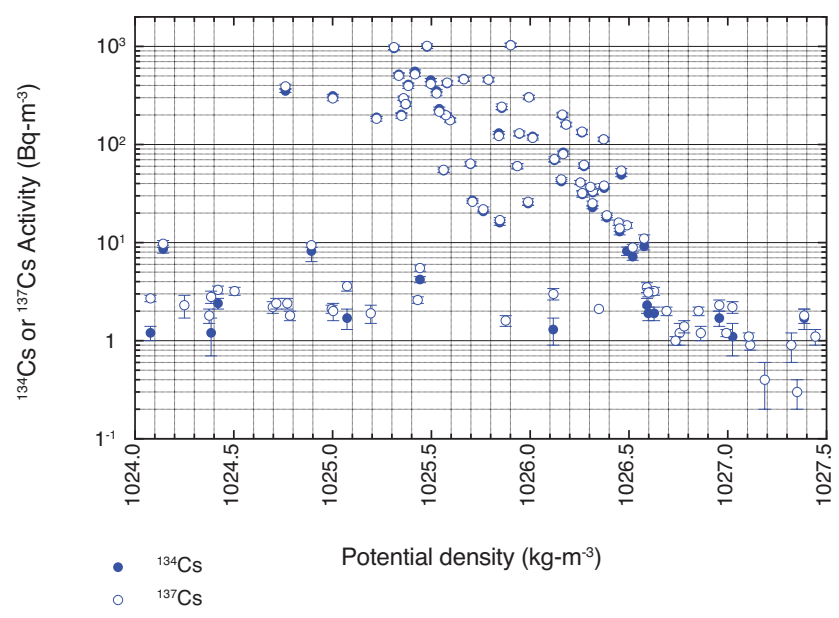

Figure 8. ${ }^{134} \mathrm{Cs}$ (filled circles) and ${ }^{137} \mathrm{Cs}$ (open circles) as a function of potential density. ${ }^{134} \mathrm{Cs}$ data are referenced (decaycorrected) to 6 April 2011. Not shown are the samples that were non-detects. Data of Buesseler et al., 2012.

${ }^{129}$ I source other than Fukushima is required to produce the increase in ${ }^{129} \mathrm{I}$ that we observe in the CCS.

\section{4 ${ }^{129}$ I budget and mixing of Fukushima-derived ${ }^{129} \mathrm{I}$ into the western Pacific}

As previously discussed, the events at the Fukushima Daiichi nuclear power plant released radionuclides into both the atmosphere and, as a consequence of fire fighting and containment efforts, directly released into the coastal ocean. Regardless of the potential chemical fractionation between cesium and iodine into volatiles, the gross correlation of ${ }^{129} \mathrm{I}$ and ${ }^{134} \mathrm{Cs}$ (evident in Fig. 5) implies that the samples collected during the June 2011 KOK cruise were dominated by direct release, or the effects of different potential input pathways were effectively homogenized in the coastal and offshore environment during the time between release and sampling. This is consistent with seawater ${ }^{131} \mathrm{I} /{ }^{137} \mathrm{Cs}$ observations made by TEPCO and MEXT during March and April 2011 (cf. Buesseler et al., 2011).

Not surprisingly, the penetration and mixing of Fukushima-derived ${ }^{129} \mathrm{I}$ is similar to that of cesium (Buesseler et al., 2012) and limited to depths shallower than $\sim 250 \mathrm{~m}$ and densities less than $1026.6 \mathrm{~kg} \mathrm{~m}^{-3}$ (Fig. 8). In general, and due to increased turbulence, mixing is to greater depth (larger isopycnal densities) in the nearshore stations versus those further offshore. Similar penetration depths are inferred from two ${ }^{129}$ I hydrographic profiles from April 2011: KT11-06 station A: $140.83^{\circ} \mathrm{E}, 38.4^{\circ} \mathrm{N}$; and B: $143.47^{\circ} \mathrm{E}, 38.28^{\circ} \mathrm{N}$ (Suzuki et al., 2013). Contrary to these independent methodologies and tracer data, the ${ }^{129} \mathrm{I}$ data of Hou et al. (2013), which were obtained from a sub-set of KOK samples, indicate penetration of ${ }^{129} \mathrm{I}$ to densities approaching $1026.9 \mathrm{~kg} \mathrm{~m}^{-3}$ or approximately $400 \mathrm{~m}$ (Fig. 9). 


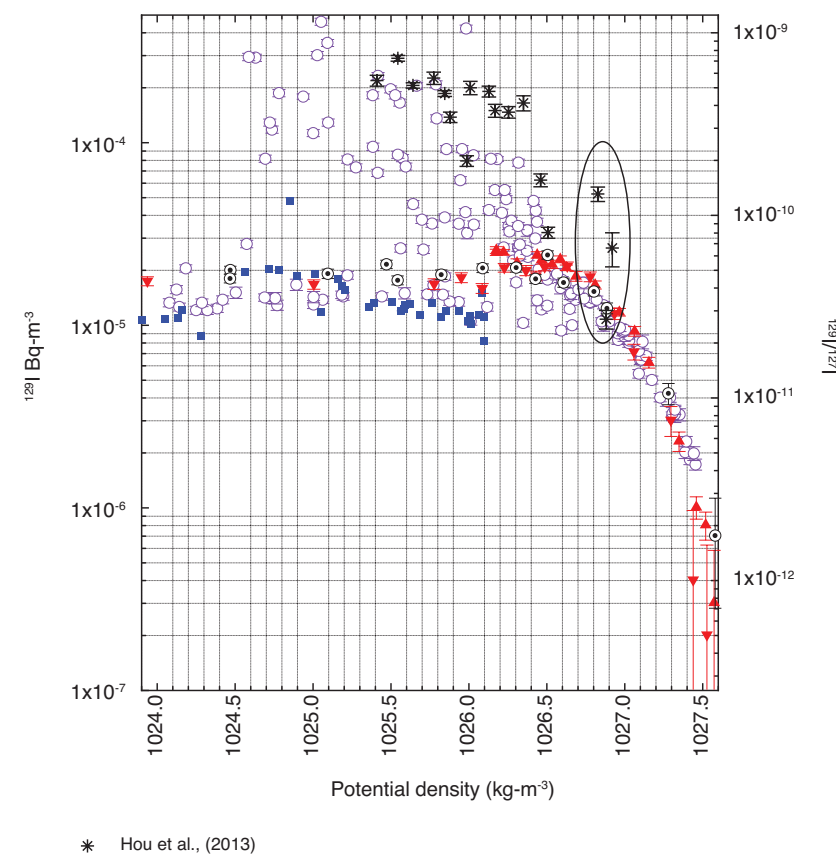

Figure 9. ${ }^{129}$ I data from figure 5 with those of Hou et al. (2013: astericks) as a function of potential density. Note the anomalous elevated ${ }^{129} \mathrm{I}$ at $1026.9\left(\mathrm{~kg} \mathrm{~m}^{-3}\right)$.

Given the consistency between the Buesseler et al. (2012) cesium data and our ${ }^{129} \mathrm{I}$ results from the same cruise, and the consistency between our ${ }^{129} \mathrm{I}$ data and that of Suzuki et al. (2013), we infer that there are unresolved issues with the Hou et al. (2013) ${ }^{129}$ I data at all depths. Thus, we restrict the discussion of the ${ }^{129} \mathrm{I}$ results and estimated excess ${ }^{129} \mathrm{I}$ budget to our data.

Following the region analysis of Buesseler et al. (2012) we construct average ${ }^{129} \mathrm{I}$ profiles for the nearshore and offshore regions of the KOK cruise (Fig. 10a and b). For internal consistency we define the pre-Fukushima ${ }^{129} \mathrm{I}$ content using the ${ }^{134} \mathrm{Cs}$ zero intercept for ${ }^{134} \mathrm{Cs}$ data $>1.5 \mathrm{~Bq} \mathrm{~m}^{-3}$ $\left({ }^{129} \mathrm{I} /{ }^{127} \mathrm{I} 2.4 \times 10^{-11}, 0.9 \times 10^{-5} \mathrm{~Bq} \mathrm{~m}^{-3}\right)$ and, via simple subtraction, calculate the excess inventory as a function of depth (Fig. 10c). The excess inventory would be $\sim 10 \%$ lower using the OOCL Tokyo observations $\left(2.75 \times 10^{-11}\right)$ and $\sim 25 \%$ lower if we chose $3.5 \times 10^{-11}$ from the nearconstant ${ }^{129} \mathrm{I}$ values as a function of density (cf. Fig. 4a) to define the pre-event ${ }^{129} \mathrm{I}$ background. The nearshore region $\left(50000 \mathrm{~km}^{2}\right)$ has an estimated excess ${ }^{129} \mathrm{I}$ inventory of $1.31 \times 10^{-2} \mathrm{~Bq} \mathrm{~m}^{-2}$ and that of the offshore region $\left(100000 \mathrm{~km}^{2}\right)$ is $5.17 \times 10^{-3} \mathrm{~Bq} \mathrm{~m}^{2}$. This leads to an upper estimate excess inventory of $\sim 1173$ million Bq of ${ }^{129} \mathrm{I}$ $\left(8.38 \times 10^{23}\right.$ atoms $)$ or $\sim 179$ grams and a lower bound estimate of 890 million $\mathrm{Bq}(\sim 136 \mathrm{~g})$ of ${ }^{129}$ I. Direct quantification of the uncertainty of this estimate is, due to the potential clustering of profiles and sampling a heterogeneous domain, difficult. Errors quoted in similar studies have been $\pm 30 \%$ or more (Buesseler et al., 2012).
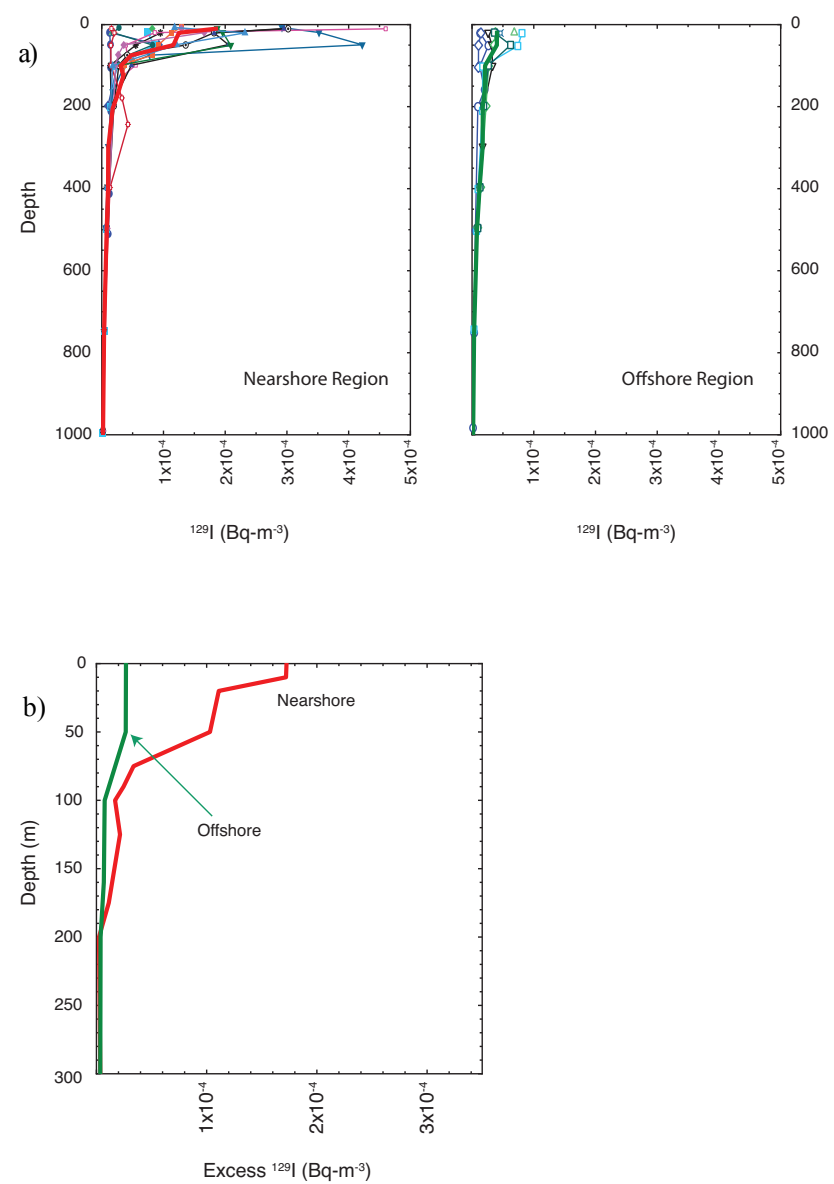

Figure 10. (a) ${ }^{129} \mathrm{I}$ as a function of depth for all profiles presented for the nearshore (Stations 17, 18, 19, 20, 21, 22, 23, 24, 25, 26, 27, 28, 29, 30, 31, 32) and offshore regions (Stations 5, 6, 7, 8, 9, 10, 11,12 ) as defined by Buesseler et al. (2012). (b) Excess ${ }^{129}$ I for the nearshore and offshore regions for depths above 300 meters.

The instantaneous excess ${ }^{129}$ I budget does not include any potential uptake due to biological activity or loss via trophic transfer or sequestration into sediments. An admittedly crude estimate of the iodine flux lost via sinking phytoplankton can be derived taking advantage of the carbon export data from the long-term sediment trap program and short-term drifting sediment traps at the KNOT, K2, and S1 sites (e.g., Honda et al., 2002; Kobari et al., 2013; see also http://ebcrpa. jamstec.go.jp/k2s1/en/dst.html). A carbon export flux of 20 $100 \mathrm{mg} \mathrm{m}^{-2}$ day $^{-1}$ and an I/C ratio of $\sim 1 \times 10^{-4}$ yields an iodine flux up to $\sim 0.01 \mathrm{mg}$ iodine $\mathrm{m}^{-2} \mathrm{day}^{-1}$. This scales to upper bound instantaneous export of $\sim 1500 \mathrm{~kg}$ iodine-day ${ }^{-1}$ for the $\sim 150000 \mathrm{~km}^{2}$ region sampled by the KOK. If we assume that the exported ${ }^{129} \mathrm{I}$ was $\sim 5 \times 10^{-10}$, which is in the mid-range of the elevated values that we observed, we estimate $\sim 0.0008$ grams of ${ }^{129}$ I were lost per day. Therefore, relative to the instantaneous dissolved ${ }^{129}$ I excess inventory (136-179 g) for the region sampled by the KOK that exported 
out of the surface waters via sinking phytoplankton during the cruise is estimated to be very small.

To determine the actual ${ }^{129} \mathrm{I}$ direct discharge release requires a model-based assessment of the mixing (dilution) within, and transport out of the KOK sampled region between the initial release and the cruise, $\sim 3$ months later. Such estimates are very likely to be model dependent and require independent knowledge of the relative influence of atmospheric and direct discharge of ${ }^{129} \mathrm{I}$. An ocean model forced with National Centers for Environmental Prediction (NCEP)National Center for Atmospheric Research (NCAR) reanalysis and satellite altimetry as described in Rypina et al. (2013) and using the KOK sampled region $2 \mathrm{PBq}$ excess inventory of cesium (Buesseler et al., 2012) implies that $~ 82.5 \%$ of the direct oceanic discharge and $\sim 95 \%$ of the atmospheric deposited $\mathrm{Cs}$ had been advected out of the region the $\mathrm{KOK}$ sampled by the time of the cruise. The convolution of the two source terms and export indicate that more than $95 \%$ of the excess cesium in the region sampled by the KOK came from direct discharge (Rypina et al., 2013). If the model results are accurate, we can use a similar dilution scaling argument to estimate an admittedly uncertain direct discharge of $\sim 1 \mathrm{~kg}$ of ${ }^{129} \mathrm{I}$. Moreover, if precise and accurate, the cesium modeling assessment allows us to estimate the actual direct discharge ${ }^{129} \mathrm{I}-{ }^{134} \mathrm{Cs}$ (and ${ }^{129} \mathrm{I}-{ }^{137} \mathrm{Cs}$ ) relation from

$0.95\left[{ }^{129} \mathrm{I} /{ }^{134} \mathrm{Cs}\right]_{\text {direct }}+0.05\left[2.1 \times 10^{-6}\right]_{\mathrm{atm}}=3.7 \times 10_{\text {observed }}^{-7}$

Solving yields $2.8 \times 10^{-7}$ (unitless activity ratio) for ${ }^{129} \mathrm{I} /{ }^{134} \mathrm{Cs}$ and $3.2 \times 10^{-7}$ for ${ }^{129} \mathrm{I} /{ }^{137} \mathrm{Cs}$.

\subsection{California Coastal Current ${ }^{129}$ I}

There were only a few NYK samples in the eastern Pacific that detected ${ }^{134} \mathrm{Cs}$ and thus implicate atmospheric deposition of ${ }^{129} \mathrm{I}$, whereas the OOCL Tokyo data show that ${ }^{129} \mathrm{I}$ in eastern surface waters is consistently elevated compared to the far western and central Pacific (Fig. 3b). Washout of atmospheric ${ }^{129}$ I by precipitation into western North American watersheds and subsequent run-off into the CCS is a potential avenue for the observed trend in ${ }^{129} \mathrm{I}$ as the OOCL Tokyo came into the CCS and approached Long Beach, CA. Indeed, analysis of seaweed samples collected in April 2011 from southern California document the presence of ${ }^{131} \mathrm{I}$ inferred to be from Fukushima (Manley et al., 2012). However, these observations and inferences do not preclude a possible North American ${ }^{129}$ I point source that could influence the ${ }^{129} \mathrm{I}$ content of the CCS, namely the Columbia River (Kilius et al., 1994; Moran et al., 2002). More recent (1998-2005) monitoring of ${ }^{129} \mathrm{I}$ in the Columbia river and watershed indicate elevated values near Richland, WA, compared to upstream at Priest Rapids Dam (Patton 2004, 2009), where ${ }^{129}$ I average concentrations range from $\sim 4.6 \times 10^{-6} \mathrm{Bql}^{-1}$ to $\sim 1.8 \times 10^{-6} \mathrm{Bql}^{-1}$. Flow rates at Priest Rapids are approximately $3000 \mathrm{~m}^{3} \mathrm{~s}^{-1}$ (Patton 2004, 2009) which implies a potential ${ }^{129}$ I source

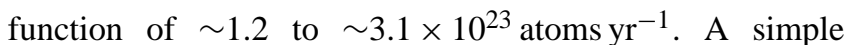
salinity-based two-endmember model using the Richland ${ }^{129} \mathrm{I}$ concentration $\left(0 \mathrm{psu}, 1.8-4.6 \times 10^{-3} \mathrm{~Bq} \mathrm{~m}^{-3}\right)$ and an "unperturbed" average eastern Pacific surface value of $1.2 \times 10^{-5} \mathrm{~Bq} \mathrm{~m}^{-3}$ (33.27 psu) from the OOCL Tokyo data allow us to infer that the CCS maximum values that we observe $\left(2.0 \times 10^{-5} \mathrm{~Bq} \mathrm{~m}^{-3}\right)$ could be accommodated with only a fraction of a percent of direct dilution of surface ocean waters with Columbia River water. Current and water mass observations within the CCS imply a residence time within the CCS of several years to multiple decades (e.g., Lynn and Simpson 1987; Auad et al., 2011). Thus, it is possible that recirculation within the CCS has allowed the ${ }^{129} \mathrm{I}$ signature from the Columbia River to accumulate. Further isolation of the ${ }^{129}$ I source and overall impact of atmospheric deposition of ${ }^{129} \mathrm{I}$ in eastern Pacific surface waters will require additional samples and radiochemical tracer-tracer analysis that can uniquely distinguish Fukushima-derived fallout from the Columbia River or other potential point sources.

\subsection{Penetration of ${ }^{129} \mathrm{I}$ into subsurface water masses}

Although the region off Fukushima has, due to the confluence of the Kuroshio and Oyahio currents, more complicated dynamics than the "open" Pacific, we can explore the ${ }^{129}$ I data in the context of a conventional transient oceanographic tracer. In this region, isopycnals are shallower and slightly compressed relative to that of the open Pacific, i.e., isopycnals deepen to the south and east entering the open North Pacific (see Fig. 3). Major reference density horizons include $1026.2 \mathrm{~kg} \mathrm{~m}^{-3}$, which outcrops at $38-40^{\circ} \mathrm{N}$ during winter and slopes downward to $500 \mathrm{~m}$ in the center of the subtropical gyre, and $1026.8 \mathrm{~kg} \mathrm{~m}^{-3}$, the main density of North Pacific Intermediate Water (NPIW; a well-defined lowsalinity, well-oxygenated water mass at 300-700 m depth which spreads across the North Pacific; Reid, 1965; Talley, 1993). NPIW is unique in that waters of this density do not outcrop in the open Pacific; NPIW is ventilated in the Sea of Ohkotsk and near the Kurils with (some) subsequent modification in the Gulf of Alaska (Aydin et al., 1998; Guilderson et al., 2006). At the time of the KOK cruise $(\sim 100$ days post event), we did not observe entrainment or mixing of Fukushima-derived radionuclides to densities greater than $\sim 1026.5 \mathrm{~kg} \mathrm{~m}^{-3}$ (Fig. 4a). The major impact of Fukushima nuclides was confined to lower densities due to the rapid expunging (relatively short residence time) of surface waters in the confluence zone and the region sampled by the KOK (e.g., Buesseler et al., 2012; Rypina et al., 2013). Moving forward in time, we anticipate that small residual (relative to the large initial direct discharge that was swept offshore) radionuclides could be mixed into higher densities. This is confirmed by the results of Suzuki et al. (2013), who observe elevated ${ }^{129} \mathrm{I}$ to $\sim 1026.9 \mathrm{~kg} \mathrm{~m}^{-3}$ in samples off Fukushima in September, five months after the accident. This is not to imply that the Fukushima radionuclides have significantly 
impacted ("labeled") NPIW and waters of deeper densities, just that the enhanced mixing in the Oyahio-Kuroshio confluence region can lead to the local input of some of the Fukushima-related products at these densities.

The pre-anthropogenic ${ }^{129} \mathrm{I} /{ }^{127} \mathrm{I}$ of the ocean has, via the analysis of sediments and archived macrophytes, been estimated to be $\leq 1.5 \times 10^{-12}$ (Moran et al., 1998). This estimate is consistent with the deep (sigma-t>1027.6) results of Suzuki et al. (2013) who report ratios equivalent to $1.2 \times 10^{-12}( \pm 100 \%)$ to as low as $3.5 \times 10^{-13}( \pm 1000 \%)$. The present-day open-Pacific distribution of anthropogenic or "bomb" ${ }^{129}$ I, uninfluenced by reprocessing or related activities, as a function of depth (density) should reflect that of a conventional "transient tracer" such as tritium except that (compared to tritium with a $\sim 12$ year half-life) there is no appreciable radioactive decay. We anticipate that waters which are ventilated or mixed on decadal timescales such as at the gyre boundary will have elevated ${ }^{129}$ I values, whereas deeper waters will have ${ }^{129} \mathrm{I}$ commensurate with the timescale of advection/mixing and isopycnal diffusion. To demonstrate this point, we compare our results and the pre-event data of Suzuki et al. (2013) to tritium observations obtained in 1993 (the World Ocean Circulation Experiment - WOCE P10) and in 2004 from a climate variability and predictability (CLIVAR) reoccupation of WOCE P02. Tritium data were obtained from the CLIVAR and Carbon Hydrographic Office (http://cchdo.ucsd.edu/pacific.html). Although from the same general location near Japan and within or at the edge of the NPSG, transport and dynamics means that the comparison is obviously not a direct comparison of the same water masses at the exact same time. The tritium data are decay corrected to a common reference year of 2010 . We chose this year to be close to the 2008 and 2009 pre-event data of Suzuki et al., and our observations in 2011. For visual clarity we restrict our (KOK) data to non-Fukushima impacted samples and densities greater than $1026.5 \mathrm{~kg} \mathrm{~m}^{-3}$ (Fig. 11). Tritium and ${ }^{129}$ I data exhibit the same general curvature and describe a typical (vertical) diffusive transient tracer profile with input at the surface (cf. Fig. 11: Kelley and Van Scoy, 1999). The curves indicate approximately the same vertical diffusivities based on tritium and ${ }^{129} \mathrm{I}$; the shape of the tritium and ${ }^{129}$ I profiles, as a function of density and if converted into a common depth domain, are similar. Thus the profiles indicate a first-order source of anthropogenic ${ }^{129} \mathrm{I}$ which is likely atmospheric deposition of ${ }^{129}$ I from initial atmospheric weapons testing with subsequent atmospheric deposition from other anthropogenic sources such as reprocessing (Toyama et al., 2012).

In contrast to these consistent atmospheric testing sourced transient tracer data, ${ }^{129} \mathrm{I}$ data from the central equatorial and western Pacific during a 1997 IAEA cruise (Povinec et al., 2000, 2010, 2013) present a large and regional elevation in ${ }^{129} \mathrm{I}$ above not only pre-anthropogenic ${ }^{129} \mathrm{I} /{ }^{127} \mathrm{I}\left(\leq 1.510^{-12}\right)$ but also above the data of Suzuki et

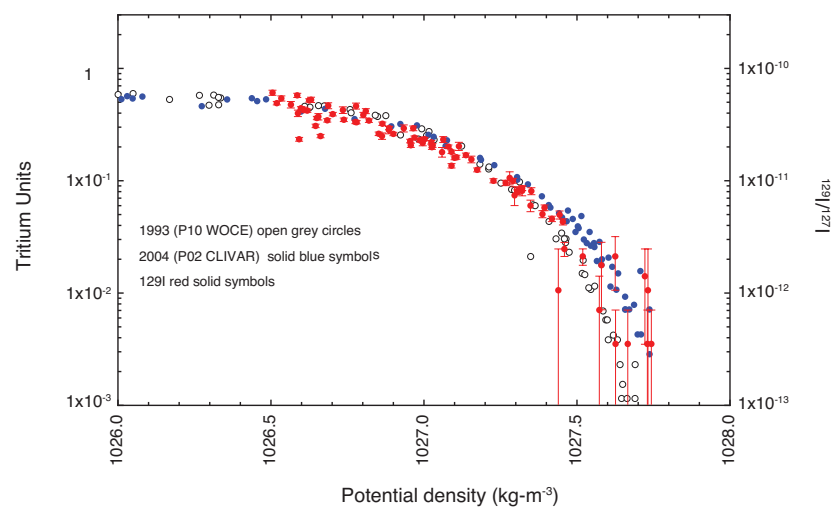

Figure 11. Tritium and ${ }^{129}$ I produced during atmospheric weapons testing will have a similar input function and penetration history in the ocean. Pre-Fukushima ${ }^{129} \mathrm{I}$ data, as ${ }^{129} \mathrm{I} /{ }^{127} \mathrm{I}$ from three hydrographic profiles to the east of Japan (Suzuki et al., 2013), and data from the KOK for densities greater than $1026.5 \mathrm{~kg} \mathrm{~m}^{-3}$ (filled red circles). Tritium data from selected stations near Japan from WOCE P10 in 1993 (stations 79, 81, 83, 85, 88, 90: open circles) and the CLIVAR reoccupation of P02 in 2004 (stations: 11, 15, 19, 23, 28: filled blue circles). Tritium data have been decay corrected to a common reference of 2010 .

al. (2010, 2013) and our own "non-Fukushima influenced" data (Fig. 12).

If real, the data from the IAEA 97 cruise indicate a significant perturbation to the North Pacific pre-anthropogenic ${ }^{129} \mathrm{I}$ budget at all sampled depths, i.e., extending to $5000 \mathrm{~m}$. ${ }^{129}$ I data from stations 2 and 3 as a function of depth (Povinec personal communication, 2013) and stations 6 and 7 (digitized from figure 3 presented in Povinec et al., 2010) were placed on density horizons using the corresponding CTD data collected during the cruise on the R/V Bosei Maru. To compare against ${ }^{129} \mathrm{I} /{ }^{127} \mathrm{I}$ ratios we assume that the IAEA 97 cruise stable iodine concentrations were similar to open ocean values, but as activity per meter cubed (or atoms/L) the comparison is exactly the same. The IAEA 97 cruise ${ }^{129}$ I values are nearly invariant below 1000 meters for the western subtropical North Pacific at ${ }^{129} \mathrm{I} /{ }^{127}$ I equal to $\sim 2.8 \times 10^{-11}\left(\sim 1.1 \times 10^{-5} \mathrm{~Bq} \mathrm{~m}^{-3}\right)$ and those from the low latitude North Pacific are $\sim 5.3 \times 10^{-11}$ $\left(\sim 2.1 \times 10^{-5} \mathrm{~Bq} \mathrm{~m}^{-3}\right)$. Upper ocean samples are also distinguished by their high values of $(5.9 \pm 1.1) \times 10^{-11}(1 \mathrm{SD}$, range: $3.9 \times 10^{-11}$ to $7.8 \times 10^{-11}$ ) for depths less than $800 \mathrm{~m}$ $\left(<1027.0 \mathrm{~kg} \mathrm{~m}^{-3}\right)$ at stations 2 and 3 , and similar densities near Bikini and Einewetak (depths shallower than $500 \mathrm{~m}$ ) average $(6.6 \pm 2.4) \times 10^{-11}\left(1 \mathrm{SD}\right.$, range: $3.2 \times 10^{-11}$ to $\left.1.1 \times 10^{-10}\right)$.

To estimate this possible perturbation to the North $\mathrm{Pa}$ cific pre-anthropogenic ${ }^{129} \mathrm{I}$ budget, we simplify the region contained by stations 2, 3, 6, and 7 (Povinec et al., 2003, 2010) to a triangle with an area in excess of $2.4 \times 10^{6} \mathrm{~km}^{2}$. We fit a smoothed polynomial to the merged ${ }^{129}$ I data presented in Fig. 9 for densities greater than 1026.9 and equal 


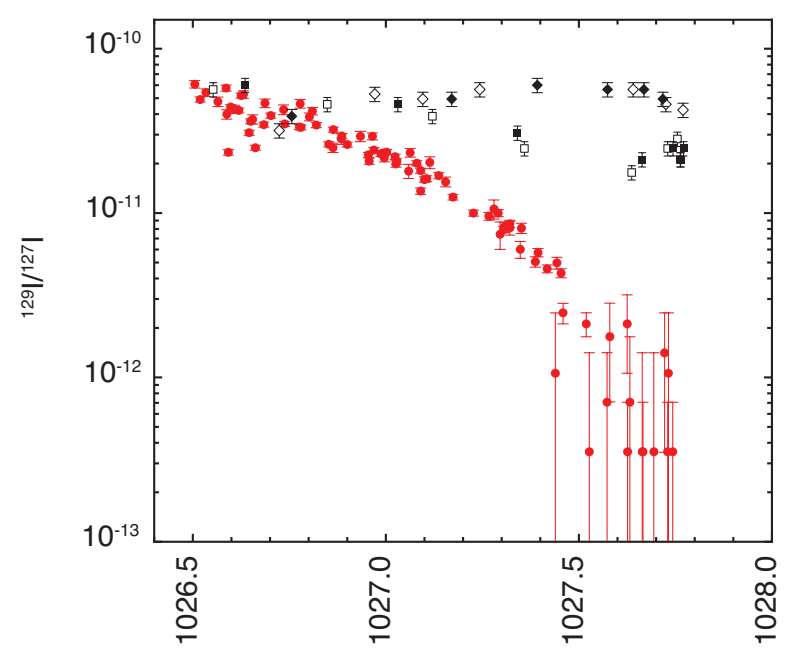

Potential density $\left(\mathrm{kg}-\mathrm{m}^{-3}\right)$

- 129 l data from figure 11

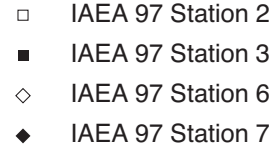

Figure 12. ${ }^{129}$ I data from Fig. 10 (filled red circles) with that from four stations during the IAEA 97 cruise presented in Povinec et al., 2010 and a sub-set replotted in Povinec et al., 2013. Note that regardless of location: western subtropical North Pacific (stations 2, 3: squares) or low latitudes near Bikini/Enewetak (stations 6, 7: diamonds) that the IAEA 97 data imply a significant ${ }^{129}$ I excess at all densities (depths to $5000 \mathrm{~m}$ sampled).

interval interpolate the data with a step of 0.1 at 0.05 density horizons (e.g., 1026.95, 1027.05, 1027.15). For shallower depths, and to account for the small ${ }^{129}$ I latitudinal dependence in surface waters observed between 36 and $44^{\circ} \mathrm{N}$, we use a constant ${ }^{129} \mathrm{I} / /^{127} \mathrm{I}$ of $2.8 \times 10^{-11}$, which is consistent with our OOCL Tokyo data for stations south of $35^{\circ} \mathrm{N}$. Differences were then calculated for the corresponding density horizons after averaging/compositing stations $2 / 3$ and $6 / 7$. Excess ${ }^{129} \mathrm{I}$ (as atoms $\mathrm{m}^{-3}$ ) were calculated and, after translating the density horizons back into the depth domain, integrated. Even accounting for the possibility of higher surface ${ }^{129} \mathrm{I}$ in 1997 relative to $2008-2011$, the excess ${ }^{129} \mathrm{I}$ is mainly due to the vast volume below the well-mixed surface layer. This admittedly coarse assessment yields an excess burden of $17-29 \mathrm{~kg}^{129}$ I relative to our composite post-bomb ${ }^{129}$ I profile in Fig. 10, or $21-32 \mathrm{~kg}$ of excess ${ }^{129} \mathrm{I}$ relative to pre-anthropogenic ${ }^{129} \mathrm{I}$. This is $20-32$ times larger than what we estimate the direct release from Fukushima NPP to have been $(\sim 1 \mathrm{~kg})$. To put this "anomaly" in perspective, the total global release of ${ }^{129} \mathrm{I}$ during atmospheric weapons testing is estimated to have been $90( \pm 50 \%) \mathrm{kg}$ (Snyder et al., 2010). From the available ${ }^{129} \mathrm{I}$ release data it is difficult to ascertain the validity of the proportionally large ${ }^{129}$ I input implied by the IAEA 97 cruise data, which is equivalent to $\sim 30 \%$ of the estimated global fallout from all atmospheric weapons testing. Intriguing as the question of where this regional pulse of ${ }^{129} \mathrm{I}$ may have gone in the intervening decades may be, it is our hypothesis that these samples inadvertently picked up ${ }^{129} \mathrm{I}$ during handling. Such inadvertent ${ }^{129} \mathrm{I}$ contamination is not unprecedented (Szidat et al., 2000).

\section{Conclusions}

We determined the excess burden of Fukushima NPP-derived ${ }^{129}$ I in a $\sim 150000 \mathrm{~km}^{2}$ region offshore Fukushima as observed in June 2011, 100 days after the catastrophe, to be $\sim 136$ to $\sim 179$ grams of ${ }^{129}$ I. Modeling (Rypina et al., 2013) of the excess ${ }^{134} \mathrm{Cs}$ and ${ }^{137} \mathrm{Cs}$ allows us to infer the total discharge into and through this region to be $\sim 1 \mathrm{~kg}$ of ${ }^{129}$ I with the majority inferred to be via direct discharge. Similar to other Fukushima-derived radionuclides, the penetration of ${ }^{129} \mathrm{I}$ was generally relegated to depths shallower than $1026.6 \mathrm{~kg} \mathrm{~m}^{-3}$, or $\sim 250 \mathrm{~m}$. We estimate the the preevent surface water ${ }^{129} \mathrm{I} /{ }^{127} \mathrm{I}$ from ${ }^{129} \mathrm{I}-{ }^{134} \mathrm{Cs}$ pairs to have been $2.4 \times 10^{-11}$ which is similar to surface water samples unlikely affected by Fukushima collected on a trans-Pacific transect: $2.75 \times 10^{-11}$.

The seawater samples describe a ${ }^{129} \mathrm{I} /{ }^{137} \mathrm{Cs}$ and ${ }^{129} \mathrm{I} /{ }^{134} \mathrm{Cs}$ unitless activity ratio of $4.1 \times 10^{-7}$ and $3.7 \times 10^{-7}$, respectively, with the ${ }^{134} \mathrm{Cs}$ being decay corrected to 11 March 2011 . The ${ }^{129} \mathrm{I} /{ }^{134} \mathrm{Cs}$ activity ratio is slightly sensitive to the decay correct reference date. If we use the April 6, 2011 date of maximum discharge (eg., Buesseler et al., 2011), the activity ratio is $3.9 \times 10^{-7}$ and indistinguishable from ${ }^{129} \mathrm{I} /{ }^{137} \mathrm{Cs}$ (95\% CI overlap). Utilizing the ocean model estimate of the relative influence of atmospheric and direct injection allows us to estimate that the direct discharge component had a ${ }^{129} \mathrm{I} /{ }^{134} \mathrm{Cs}$ activity ratio of approximately $2.8 \times 10^{-7}$ and, not surprisingly nearly the same value, $3.2 \times 10^{-7}$ for ${ }^{129} \mathrm{I} /{ }^{137} \mathrm{Cs}$. The activity ratio of direct discharge is an order of magnitude less than that implied by aerosol and related data: $2.1 \times 10^{-6}$.

Surface water samples from in and near the California Coastal Current System have slightly elevated ${ }^{129}$ I values compared with waters to the west. Samples taken during a May 2011 VOS container ship transit document approximately constant ${ }^{129} \mathrm{I} /{ }^{127} \mathrm{I}$ values from Hong Kong to $\sim 161 \mathrm{~W}$ of $\sim 3 \times 10^{-11}$ or less, whereas values in the CCS are $\sim 5.3 \times 10^{-11}$. Although it is possible that these slightly elevated values are due to atmospheric deposition of Fukushima releases, we hypothesize that the CCS is impacted by ${ }^{129} \mathrm{I}$ from the Columbia River: from past input of ${ }^{129}$ I through the Columbia River which due to recirculation and the residence time of water within the CCS has accumulated, as well as continued, and perhaps smaller, ${ }^{129} \mathrm{I}$ input from the Columbia River. 
Acknowledgements. We are grateful to the captain and crew of the R/V Ka'imikai-o-Kanaloa and all participants of the science party for a successful cruise. We are especially grateful to the University of Hawaii Marine Center and SOEST who rescheduled an existing cruise to give the Fukushima expedition priority. $\mathrm{S}$ Pike (WHOI) and T Broek (UCSC) coordinated the sea-going sampling. We thank $\mathrm{M}$ Aoyama and $\mathrm{P}$ Povinec for providing a subset of data tables. The R/V Bosei Maru CTD data for the IAEA 97 cruise were courteously provided by Y Niimura of the Japanese Oceanographic Data Center. P Durack generated the MCSST raster image in Fig. 1a. The final manuscript benefited from the comments and criticisms of X. Hou, P. Povinec, G. Snyder, and two anonymous reviewers. In the laboratory we thank $\mathrm{H}$ Seidler and A Glimme, both high school science teachers who, through the Edward Teller Education Center (LLNL), assisted in iodine separation chemistry. A significant portion of this research was funded by the Gordon and Betty Moore Foundation through Grant GBMF3007 to K. Buesseler. OOCL Tokyo samples were courtesy of P Quay and H Palevsky (University of Washington) and collected under funding provided by NOAA OGP. This work was performed under the auspices of the U.S. Department of Energy by Lawrence Livermore National Laboratory under contract DE-AC52-07NA27344. Data will be digitally archived at the Biological and Chemical Oceanography Data Management Office; this is LLNL-JRNL-644922.

Edited by: M. Dai

\section{References}

Aoyama, M., Tsumune, D., and Hamajima, Y.: Distribution of 137Cs and 134Cs in the North Pacific Ocean: impacts of TEPCO Fukushima-Daiichi NPP accident, J. Radioanal. Nucl. Ch., 1-5, doi:10.1007/s10967-012-2033-2, 2012.

Aoyama, M., Uematsu, M., Tsumune, D., and Hamajima, Y.: Surface pathway of radioactive plume of TEPCO Fukushima NPP1 released ${ }^{134} \mathrm{Cs}$ and ${ }^{137} \mathrm{Cs}$, Biogeosciences, 10, 30673078, doi:10.5194/bg-10-3067-2013, 2013.

Achim, P., Monfort, M., Le Petit, G., Gross, P., Douyesset, G., Taffary, T., Blanchard, X., and Moulin, C: Analysis of radionuclide releases from the Dai-ichi Nuclear Power Plant, Part II., Pure Appl. Geophys., doi:10.1007/s00024-012-0578-1, 2012.

Auad, G., Roemmich, D., and Gilson, J.: The California Current System in realtin to the Northeast Pacific Ocean circulation, Prog. Oceanogr., 91, 576-592, 2011.

Aydin, M., Top, Z., Fine, R. A., and Olson, D. B.: Modification of the intermediate waters: I. the northeastern subpolar Pacific, J. Geophys. Res., 103, 30924-30940, 1998.

Barkley, R. A. and Thompson, T. G.: The total iodine and iodateiodine content of sea-water, Deep-Sea Res., 7, 24-34, 1960.

Biegaleski, S. R., Eslinger, P. W., Friese, J. A., Greenwood, L. R., Haas, D. A., Hayes, J. C., Hoffman, I., Keillor, M., Miley, H. S., and Moring M.: Analysis of data from sensitive US monitoring stations for the Fukushima Dai-ichi nuclear reactor accident, J. Environ. Radioactiv., 114, 15-21, 2012.

Broecker, W. S. and Peng, T. H.: Tracers in the Sea, ELDIGIO Press, Palisades NY, 1982.
Buesseler, K. O., Aoyama, M., and Fukasawa, M.: Impacts of the Fukushima Nuclear Power Plants on Marine Radioactivity, Environ. Sci. Technol., 45, 9931-9935, 2011.

Buesseler, K. O., Jayne, S. R., Fisher, N. S., Rypina, I. I., Baumann, H., Baumann, Z., Breier, C. F., Douglass, E. M., George, J., Macdonald, A. M., Miyamoto, H., Nishikawa, J., Pike, S. M., and Yoshida, S.: Fukushima-derived radionuclides in the ocean and biota off Japan, Proc. Natl. Acad. Sci., www.pnas.org/cgi/doi/10. 1073/pnas.1120794109, 2012.

Caput, C., Camus, H., Gauthier, D., and Belot, Y.: Etude experimentale du lavage de l'iode par la pluie, Radioprotection, 28, 15-22, 1993.

Edmonds, H. N., Zhou, Z. Q., Raisbeck, G. M., Yiou, F., Kilius, L., and Edmond, J. N.: Distribution and behavior of anthropogenic ${ }^{129} \mathrm{I}$ in water masses ventilating the North Atlantic Ocean, J. Geophys. Res., 106, 6881-6894, 2001.

Elderfield, H. and Truesdale, V. W.: On the biophilic nature of iodine in seawater, Earth Planet. Sc. Lett., 50, 105-114, 1980.

Fehn, U., Tullai-Fitzpatrick, S., Kubik, P. W., Sharma, P., Teng, R. T. D., Gove, H. E., and Elmore, D.: ${ }^{129} \mathrm{I}$ and ${ }^{36} \mathrm{Cl}$ concentrations in waters of the eastern Clear Lake area, California: residence times and sources ages of hydrothermal fluids, Geochim. Cosmochim. Ac., 56, 2069-2079, 1992.

Feng, M., Mitsudera, H., and Yoshikawa, Y.: Structure and variability of the Kuroshio Current in Tokara Strait, J. Phys. Oc., 30, 2257-2276, 2000.

Guilderson, T. P., Southon, J. R., and Brown, T. A.: "HighPrecision" AMS- ${ }^{14} \mathrm{C}$ Results on TIRI Turbidite, Radiocarbon, 45, 75-80, 2003.

Guilderson, T. P., Roark, E. B., Quay, P. D., Flood-Page, S. R., and Moy, C.: Seawater radiocarbon evolution in the Gulf of Alaska: 2002 observations, Radiocarbon, 48, 1-15, 2006.

Hoffman, I., Korpach, E., Mekarski, P., Ungar, K., Yi, J., Zhang, W., Moring, M., Khotylev, V., and El-Jaby, A.: Fukushima event reconstruction using modeling and isotope relationships, J. Radioanal. Nucl. Ch., 296, 1091-1098, doi:10.1007/s10967-0122124-0, 2012.

Honda, M. C., Imai, K., Nojiri, Y., Hoshi, F., Sugawara, T., and Kusakabe, M.: The biological pump in the northwestern North Pacific based on fluxes and major components of particulate matter obtained by sediment-trap experiments (1997-2000), Deep Sea Res. Pt. II, 49, 5595-5625, 2002.

Hou, X., Povinec, P. P., Zhang, L., Shi, K., Biddulph, D., Chang, C-C., Fan, Y., Gosler, R., Hou, Y., Jeskovsky, M., Jull, A. J. T., Liu, Q., Luo, M., Steier, P., and Zhou, W.: Iodine-129 in seawater offshore Fukushima: distribution, inorganic speciation, sources, and budget, Environ Sci. Tech., 47, 3091-3098, doi:10.1021/es304460k, 2013.

Ito, S. and Yasuda, I.: Characteristics of mesoscale eddies in the Kuroshio-Oyashio extension region detected from the distribution of the sea surface height anomaly, J. Phys. Oceanogr., 40, 1018-1034, 2010.

Kelley, D. E. and Van Scoy, K. A.: A basinwide estimate of vertical mixing in the upper pycnocline: Spreading of bomb tritium in the North Pacific Ocean, J. Phys. Oceanogr., 29, 1759-1771, 1999.

Kilius, L. R., Rucklidge, J. C., and Soto, C.: The dispersal of ${ }^{129} \mathrm{I}$ from the Columbia River estuary, Nucl. Instr. Meth. Phys. Res. B, 92, 393-397, 1994. 
Kobari, T., Kitamura, M., Minowa, M., Isami, H., Akamatsu, H., Kawakami, H., Matsumoto, K., Wakita, M., and Honda, M. C.: Impacts of the wintertime mesozooplankton community to downward carbon flux in the subarctic and subtropical Pacific Oceans, Deep-Sea Res. Pt. I, 81, 78-88, 2013.

Kristiansen, N. I., Stohl, A., and Wotawa, G.: Atmospheric removal times of the aerosol-bound radionuclides ${ }^{137} \mathrm{Cs}$ and ${ }^{131}$ I measured after the Fukushima Dai-ichi nuclear accident - a constraint for air quality and climate models, Atmos. Chem. Phys., 12, 10759-10769, doi:10.5194/acp-12-10759-2012, 2012.

Lynn, R. J. and Simpson, J. J.: The California Current System: The Seasonal Variability of its Physical Characteristics, J. Geophys. Res., 92, 12947-12966, 1987.

Masson, O., Bieringer, J., Brudecki, K., Bucci, S., Cappai, M., Carvalho, F. P., Connan, O., Cosma, C., Dalheimer, A., Didier, D., Depuydt, G., De Geer, L. E., De Vismes, A., Gini, L., Groppi, F., Gudnason, K., Gurriaran, R., Hainz, D., Halldorsson, O., Hammond, D., Hanley, O., Hole, K., Homoki, Zs., Ioannidou, A., Isajenko, K., Jankovic, M., Katzlberger, C., Kettunen, M., Kierepko, R., Kontro, R., Kwakman, P. J. M., Lecomte, M., Leon Vintro, L., Leppanen, A. P., Lind, B., Lujaniene, G., McGinnity, P., McMahon, C., Mala, H., Manenti, S., Manolopoulou, M., Mattila, A., Mauring A., Mietelski, J. W., Møller, B., Nielsen, S. P., Nikolic, J., Overwater, R. M. W., Palsson, S. E., Papastefanou, C., Penev, I., Pham, M. K., Povinec, P. P., Rameback, H., Reis, M. C., Ringer, W., Rodriguez, A., Rulik, P., Saey, P. R. J., Samsonov, V., Schlosser, C., Sgorbati, G., Silobritiene, B. V., Söderström, C., Sogni, R., Solier, L., Sonck, M., Steinhauser, G., Steinkipff, T., Steinmann, P., Stoulos, S., Sykora, I., Todorovic, D., Tooloutalaie, N., Tositti, L., Tschiersch, J., Ugron, A., Vagena, E., Vargas, A., Wershofen, and Zhukova, O.: Tracking of airborne radionuclides from the damaged Fukushima Dai-ichi nuclear reactors by European networks, Environ. Sci. Technol., 45, 7670-7677, 2012.

Manley, S. L. and Lowe, C. G.: Canopy-forming kelps as California's coastal dosimeter: ${ }^{131}$ I from damaged Japanese ractor measured in Macrocystis pyrifera, Environ. Sci. Technol., 46, 37313736, 2012.

Michel, R., Daraoui, A., Gorny, M., Jakob, D., Sachse, R., Tosch, L., Nies, H., Goroncy, I., Hermann, J., Synal, H-A., Stocker, M., and Alfimov, V.: Iodine-129 and iodine-127 in European seawater and in precipitation from Northern Germany. Sci. Total Environment, 419, 151-169, 2012.

Miyake, Y., Matsuzaki, H., Fujiwara, T., Saito, T., Yamagata, T., Honda, M., and Muramatsu, Y.: Isotopic ratio of radioactive iodine $\left({ }^{129} \mathrm{I} /{ }^{131} \mathrm{I}\right)$ released from Fukushima Daiichi NPP accident, Geochem. J., 46, 327-333, 2012.

Moran, J., Fehn, U., and Teng., R. T. D.: Variations in ${ }^{129} \mathrm{I} /{ }^{127} \mathrm{I}$ ratios in recent marine sediments: evidence for a fossil organic component, Chem. Geol., 152, 193-203, 1998.

Moran, J., Oktay, S. D., and Santschi, P. H.: Sources of iodine and iodine 129 in rivers, Water Resour. Res., 38, 1149, doi:10.1029/2001WR00062, 2002.

Nakayama, E., Suzuki, Y., Fujiwara, K., and Kitano, Y.: Chemical analyses of seawater for trace elements, Recent progress in Japan on clean sampling and chemical speciation of trace elements, a review, Anal. Sci., 5, 129-139, 1989.
Patton, G. W.: Surface Water and Sediment Surveillance, Section 4.2 in Hanford Site Environmental Report for Calendar Year 2003, PNNL-14687, 2004.

Patton, G. W.: Surface Water and Sediment Surveillance, Section 8.4 in Hanford Site Environmental Report for Calendar Year 2009, PNNL-19455, 2009.

Povinec, P. P., Oregioni, B., Jull, A. J. T., Kieser, W. E., and Zhao, X.-L.: AMS measurements of ${ }^{14} \mathrm{C}$ and ${ }^{129} \mathrm{I}$ in seawater around radioactive waste dump sites, Nucl. Instr. Methods Phys. Res., B., 172, 672-678, 2000.

Povinec, P. P., Livingston, H. D., Shima, S., Aoyama, M., Gastaud, J., Goroncy, I., Hirose, K., Huynh-Ngoc, L., Ikeuchi, Y., Ito, T., La Rosa, J., Kwong, L. L. W., Lee, S-H., Moriya, H., Mulsow, S., Oregioni, B., Pettersson, H., and Togawa, O.: IAEA ' 97 expedition to the NW Pacific Ocean - results of oceanographic and radionuclide investigations of the water column, Deep-Sea Res. Pt. II, 50, 2607-2637, 2003.

Povinec, P. P., Lee, S.-H., Liong Wee Kwong, L., Pregioni, B., Jull, A. J. T., Kieser, W. E., Morgenstern, U., and Top, Z.: Tritium, radiocarbon, ${ }^{90} \mathrm{Sr}$, and ${ }^{129} \mathrm{I}$ in the Pacific and Indian Oceans, Nucl. Instr. Meth. Phys. Res. B., 268, 1214-1218, 2010.

Povinec, P. P., Aoyama, M., Biddulph, D., Breier, R., Buesseler, K., Chang, C. C., Golser, R., Hou, X. L., Ješkovský, M., Jull, A. J. T., Kaizer, J., Nakano, M., Nies, H., Palcsu, L., Papp, L., Pham, M. K., Steier, P., and Zhang, L. Y.: Cesium, iodine and tritium in NW Pacific waters - a comparison of the Fukushima impact with global fallout, Biogeosciences, 10, 5481-5496, doi:10.5194/bg-10-5481-2013, 2013.

Qu, T., Mitsudera, H., and Qiu, B.: A climatological view of the Kuroshio/Oyahio system east of Japan, J. Phys. Oceanogr., 31, 2575-2589, 2001.

Reid, J. L.: Intermediate waters of the Pacific Ocean, The Johns Hopkins Oceanographic Studies, 2, 85 pp., 1965.

Reid, J. L. and Mantyla, A. W.: On the Mid-Depth Circulation of the North Pacific Ocean, J. Phys. Oceanog., 8, 946-951, 1978.

Rommenich, D. and McCallister, T.: Large scale circulation of the North Pacific Ocean, Prog. Oceanog., 22, 171-204, 1989.

Rypina, I. I., Jayne, S. R., Yoshida, S., Macdonald, A. M., Douglass, E., and Buesseler, K.: Short-term dispersal of Fukushima-derived radionuclides off Japan: modeling efforts and model-data intercomparison, Biogeosciences, 10, 49734990, doi:10.5194/bg-10-4973-2013, 2013.

Schnabel, C., Olive, V., Atarashi-Andoh, M., Dougans, A., Ellam, R. M., Freeman, S., Maden, C., Stocker, M., Synal, H-A., Wacker, L., and Xu, S.: ${ }^{129} \mathrm{I} /{ }^{127} \mathrm{I}$ ratios in Scottish coastal surface sea water: Geographical and temporal responses to changing emissions, Appl. Geochem., 22, 619-627, 2007.

Smith, J. N., McLaughlin, F. A., Smethie, W. M., Moran, S. B., and Lepore, K.: Iodine-129, ${ }^{137} \mathrm{Cs}$, and CFC-11 tracer transit time distributions in the Arctic Ocean, J. Geophys. Res., 116, C040224, doi:10.1029/2010JC006471, 2011.

Snyder, G., Aldahan, A., and Possnert, G.: Global distribution and long-term fate of anthropogenic ${ }^{129} \mathrm{I}$ in marine and surface water reservoirs, Geochem. Geophys. Geosyst., 11, Q04010, doi:10.1029/2009GC002910, 2010.

Stark, S., Jenkins, W. J., and Doney, S. C.: Deposition and recirculation of tritium in the North Pacific Ocean, J. Geophys. Res., 109, C06009, doi:10.1029/2003JC002150, 2004. 
Suzuki, T., Kabuto, S., Amano, H., and Togawa, O.: Measurement of iodine-129 in seawater collected from the Japan Sea area using accelerator mass spectrometry: Contributions of nuclear fuel reprocessing plants, Quat. Geochronol., 3, 268-275, 2008.

Suzuki, T., Minakawa, M., Amano, H., and Togawa, O.: The vertical profiles of iodine-129 in the Pacific Ocean and the Japan Sea before the routine operation of a new nuclear fuel reprocessing plant, Nucl. Instr. Meth. Phys. Res., B., 268, 1229-12231, 2010.

Suzuki, T., Otosaka, S., Kuwabara, J., Kawamura, H., and Kobayashi, T.: Iodine-129 concentration in seawater near Fukushima before and after the accident at the Fukushima Daiichi Nuclear Power Plant, Biogeosciences, 10, 3839-3847, doi:10.5194/bg-10-3839-2013, 2013.

Szidat, S., Schmidt, A., Handl, J., Jakob, D., Botsch, W., Michel, R., Synal, H.-A., Schnabel, C., Suter, M., Lopez-Gutierrez, J. M., and Städe, W.,: Iodine-129 Sample preparation, quality control and analyses of pre-nuclear materials and of natural waters from Lower Saxony, Germany, Nucl. Inst. Meth. Phys. Res. B, 172, 699-710, 2000.
Talley, L. D.: Distribution and formation of North Pacific intermediate water, J. Phys. Oceanogr., 23, 517-537, 1993.

Toyama, C., Muramatsu, Y., Uchida, Y., Igarashi, Y., Aoyama, M., and Matsuzaki, H.: Variations of ${ }^{129} \mathrm{I}$ in the atmospheric fallout of Tokyo, Japan: 1963-2003, J. Env. Radiocativ., 113, 116-122, 2012.

Tumey, S. J., Guilderson, T. P., Brown, T. A., Broek, T., and Buesseler, K. O.: Input of ${ }^{129} \mathrm{I}$ into the western Pacific ocean resulting from the Fukushima nuclear event, Meth. Appl. Radioanal. Chem., 296, 957-962, doi:10.1007/s10967-012-2217-9, 2013.

Uemetsu, M., Merril, J. T., Patterson, T. L., Duce, R. A., and Prospero, J. M.: Aerosol residence times and iodine gas/particle conversion over the North Pacific as determined from Chernobyl radioactivity, Geochem. J., 22, 157-163, 1988.

Zheng, J., Takata, H., Tagami, K., Aono, T., Fujita, K., and Uchida, S.: Rapid determination of total iodine in Japanese coastal seawater using SF-ICP-MS, Microchem. J., 100, 42-47, 2012. 